\title{
GENETIC POLYMORPHISMS OF RAGE, NOD1 AND B-DEFENSINS IN MULTIPLE SCLEROSIS, STROKE AND PANCREATITIS
}

Ph.D. Thesis

\section{Zoltán László Tiszlavicz, M.D.}

\author{
Supervisor: Prof. Yvette Mándi, M.D., Ph.D., D.Sc. \\ Department of Medical Microbiology and Immunobiology \\ Faculty of Medicine \\ University of Szeged
}

Szeged

2011. 


\section{Publications related to the subject of the Thesis:}

I. Tiszlavicz Z, Szabolcs A, Takács T, Farkas G, Kovács-Nagy R, Szántai E, Sasvári-Székely M, Mándi Y. Polymorphisms of beta defensins are associated with the risk of severe acute pancreatitis. Pancreatology. 2010;10(4):483-90.

IF: 2.195 (2009)

II. Tiszlavicz Z, Endrész V, Németh B, Megyeri K, Orosz L, Seprényi G, Mándi Y. Inducible expression of human \{beta\}-defensin 2 by Chlamydophila pneumoniae in brain capillary endothelial cells. Innate Immun. $2010 \mathrm{Jul}$ 20. [Epub ahead of print] doi: 10.1177/1753425910375582

IF: 2.206 (2009)

III. Tiszlavicz Z, Gyulai Z, Bencsik K, Szolnoki Z, Kocsis AK, Somogyvári F, Vécsei L, Mándi Y. RAGE gene polymorphisms in patients with multiple sclerosis. J Mol Neurosci. 2009 Nov;39(3):360-5.

IF: 2.72

IV. Tiszlavicz Z, Somogyvári F, Kocsis AK, Szolnoki Z, Sztriha LK, Kis Z, Vécsei L, Mándi Y. Relevance of the genetic polymorphism of NOD1 in Chlamydia pneumoniae seropositive stroke patients. Eur J Neurol. 2009 Nov;16(11):1224-9.

IF: 2.51

Publications not related to the subject of the Thesis:

Tiszlavicz Z, Németh B, Fülöp F, Vécsei L, Tápai K, Ocsovszky I, Mándi Y. Different inhibitory effects of kynurenic acid and a novel kynurenic acid analogue on tumour necrosis factor- $\alpha$ (TNF- $\alpha$ ) production by mononuclear cells, HMGB1 production by monocytes and HNP1-3 secretion by neutrophils. Naunyn Schmiedebergs Arch Pharmacol. 2011 Feb 19. [Epub ahead of print]

IF: 2.631 (2009)

Kocsis AK, Ocsovszky I, Tiszlavicz L, Tiszlavicz Z, Mándi Y. Helicobacter pylori induces the release of alpha-defensin by human granulocytes. Inflamm Res. 2009 May;58(5):241-7.

IF: 1.586

Kocsis AK, Kiss ZF, Tiszlavicz L, Tiszlavicz Z, Mándi Y. Potential role of human beta-defensin 1 in Helicobacter pylori-induced gastritis. Scand J Gastroenterol. 2009;44(3):289-95.

IF: 2.084 


\section{AbBreviations}

AGE advanced glycation end products

AGER advanced glycosylation end product-specific receptor

AMP antimicrobial peptide

AP acute pancreatitis

ATTC American Type Culture Collection

$\mathrm{bp}$

base pair

BSA bovine serum albumin

CARD caspase activation and recruitment domain

cDNA complementary DNA

CNV copy number variation

$\mathrm{C}_{\mathrm{T}} \quad$ threshold cycle

DAMP danger associated molecular pattern

DNA dezoxyribonucleic acid

ELISA enzyme linked immunosorbent assay

ERCP endoscopic retrograde cholangiopancreatography

FAM 6-carboxyfluorescein

FCS fetal calf serum

FITC fluorescein isothiocyanate

GAPDH glyceraldehyde-3-phosphate dehydrogenase

HBD human beta defensin

HD human defensin

HMGB1 high mobility group box 1 protein

HNP human neutrophil peptide

iE-DAP D- $\gamma$-Glu-meso-diaminopimelic acid

IFN interferon

IFU inclusion forming unit

Ig immunoglobulin

IL interleukin

LPS lipopolysaccharide

LRR leucine rich repeat

Mac-1 macrophage-1 antigen

MAPK mitogen-activated protein kinase 
MOI multiplicity of infection

MOMP major outer membrane protein

MRI magnetic Resonance Imaging

MS multiple sclerosis

$\mathrm{NF}-\kappa \mathrm{B} \quad$ nuclear factor- $\kappa \mathrm{B}$

NLR Nod-like receptor

NOD nucleotide-binding oligomerization domain

OR odds ratio

PAMP pathogen-associated molecular patterns

PBS phosphate buffered saline

PCR polymerase chain reaction

PP primary progressive

PRR pattern-recognition receptor

RAGE receptor for advanced glycation end products

RFLP restriction fragment length polymorphism

RLR Rig-I-like receptors

RNA ribonucleic acid

ROS reactive oxygen species

RR relapsing-remitting

RT-PCR real-time reverse transcription PCR

SAP severe acute pancreatitis

SDS Sequence Detection System

SDS-PAGE sodium dodecyl sulfate polyacrilamide gel electrophoresis

SNP single nucleotide polymorphism

SP secondary progressive

TLR Toll like receptor

TNF tumor necrosis factor

UTR 5'-untranslated region 


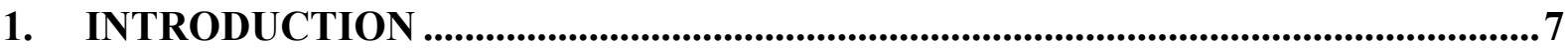

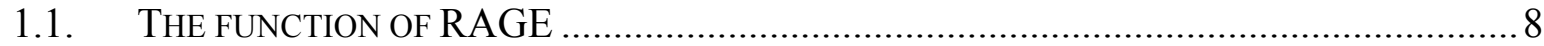

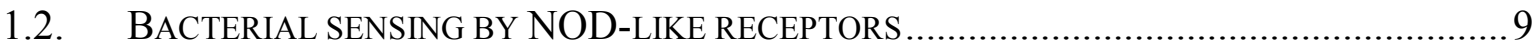

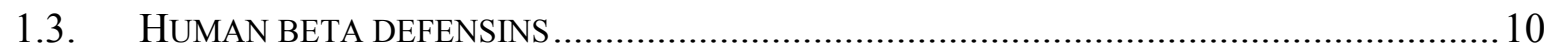

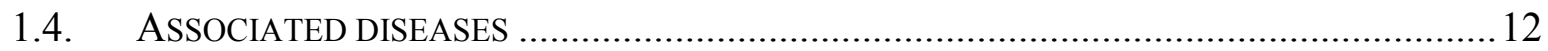

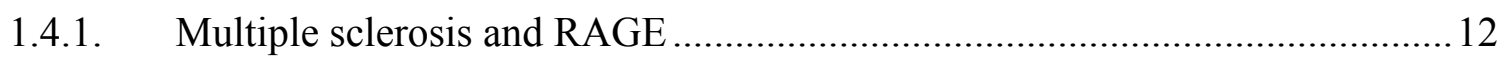

1.4.2. Acute ischemic stroke, Chlamydophila pneumoniae infection and NOD1 ...... 12

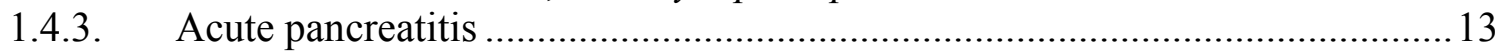

1.5. DEFENSIN INDUCTION BY CHLAMYDOPHILA PNEUMONIAE ............................................ 14

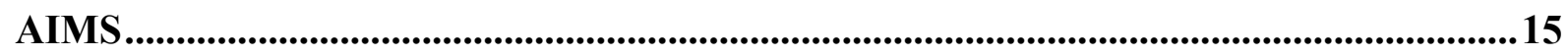

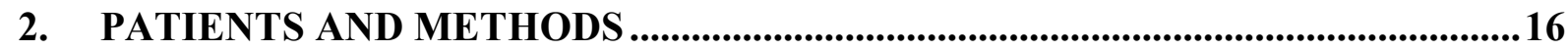

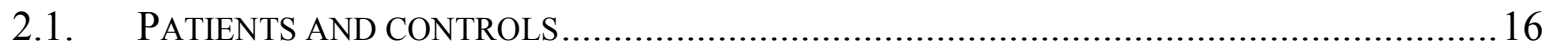

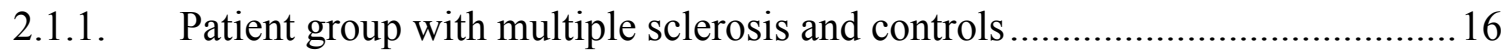

2.1.2. Patient group with acute ischemic stroke and controls................................... 16

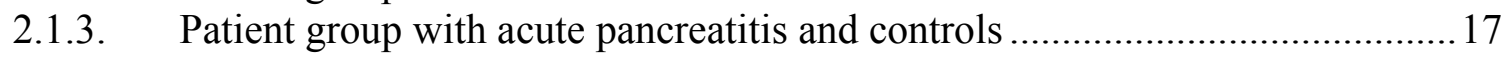

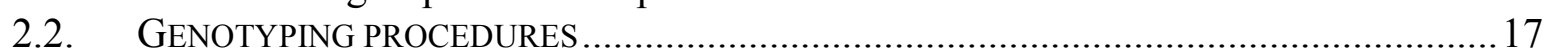

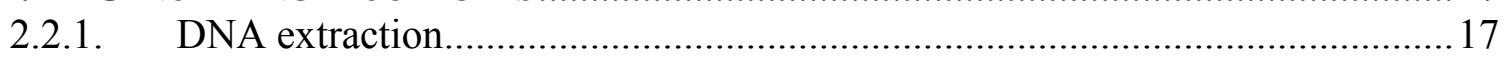

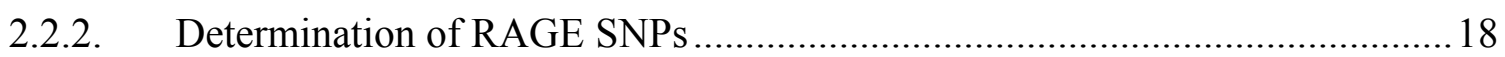

2.2.3. Determination of c.796G $>$ A polymorphism of NOD1 ................................... 19

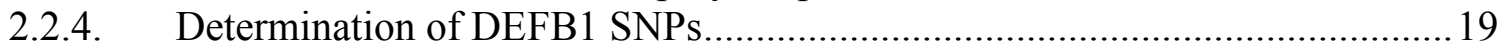

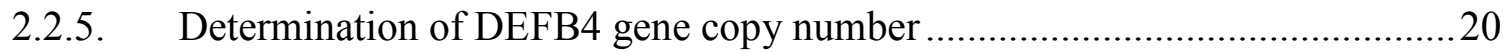

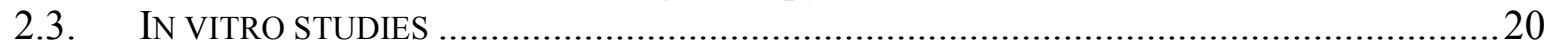

2.3.1 Cell line and in vitro infection with Chlamydophila pneumoniae....................20

2.3.2. RNA isolation from BB-19 cell lysates and PCR amplification .......................21

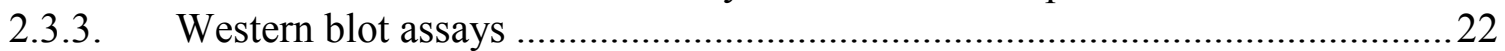

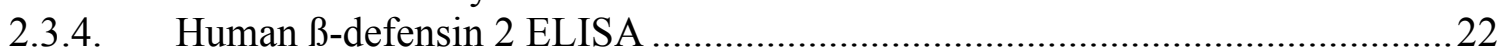

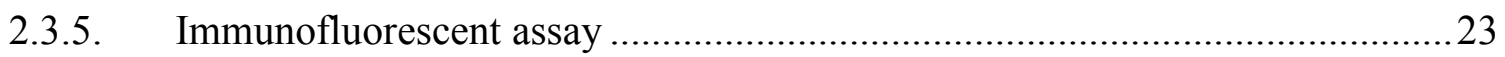

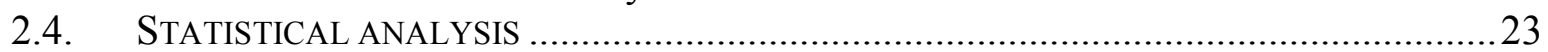

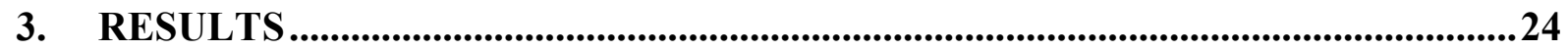

3.1. RAGE Gene Polymorphisms In PATIENTS With Multiple SCLEROSIS ..................24

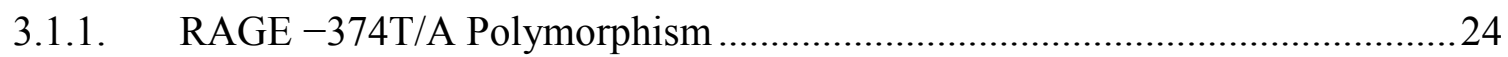

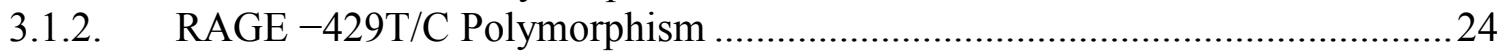

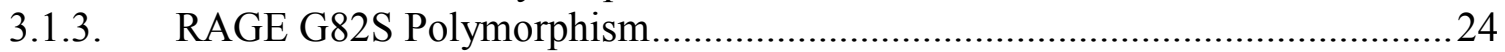

3.2. NOD1 C.796G $>$ A POLYMORPHISM AMONG CHLAMYDOPHILA PNEUMONIAE

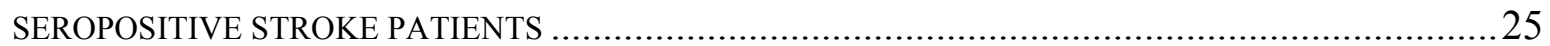

3.3. GENETIC POLYMORPHISMS OF BETA-DEFENSINS IN SEVERE ACUTE PANCREATITIS .....27

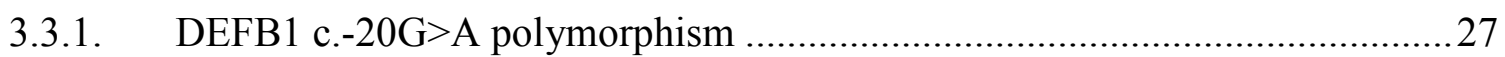

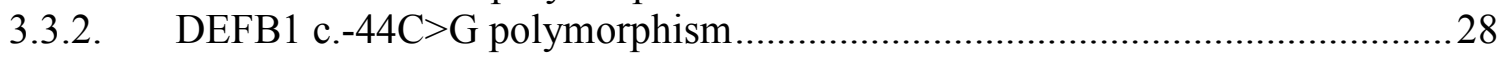

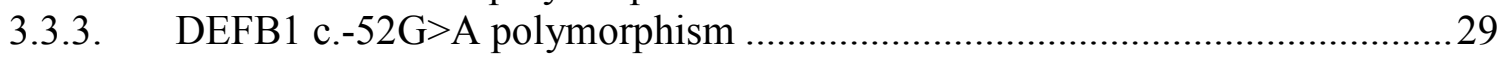

3.3.4. Copy number polymorphism of human beta-defensin-2 ….............................30

3.4. INDUCIBLE EXPRESSION OF HUMAN B-DEFENSIN 2 BY CHLAMYDOPHILA PNEUMONIAE

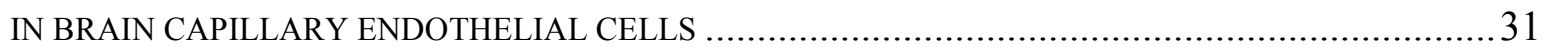

3.4.1. Expression of human $\beta$-defensin 2 mRNA in BB19 cells and increase in

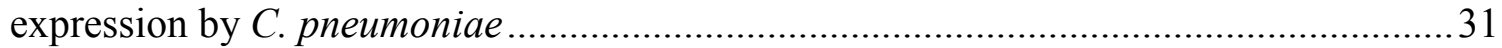

3.4.2. Human $\beta$-defensin 2 protein expression in BB19 cells infected with $C$.

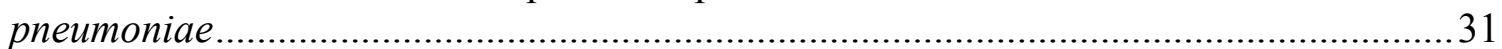

3.4.3. Immunofluorescent staining of BB19 cells for HBD-2 .................................... 33

3.4.4. Chlamydophila pneumoniae induces HBD-2 secretion by BB19 cells ..............33

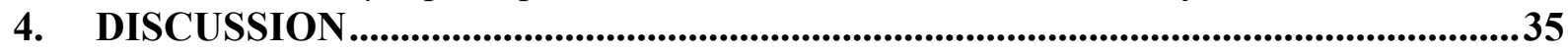

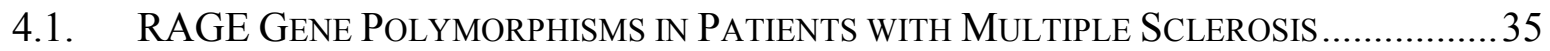


4.2. RELEVANCE OF THE GENETIC POLYMORPHISM OF NOD1 IN CHLAMYDOPHILA

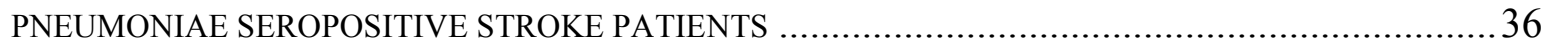

4.3. RELEVANCE OF GENETIC POLYMORPHISMS OF BETA-DEFENSINS IN SEVERE ACUTE

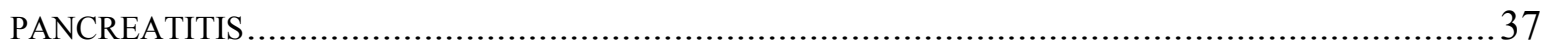

4.4. INDUCIBLE EXPRESSION OF HUMAN B-DEFENSIN 2 BY CHLAMYDOPHILA PNEUMONIAE

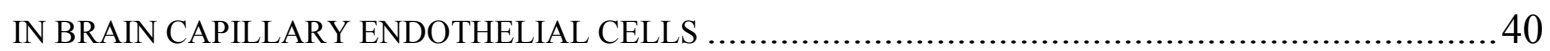

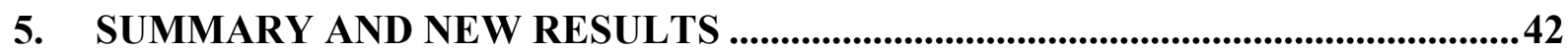

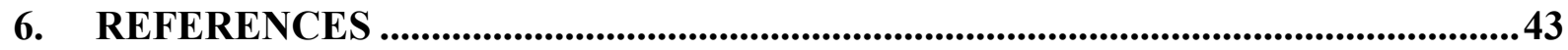

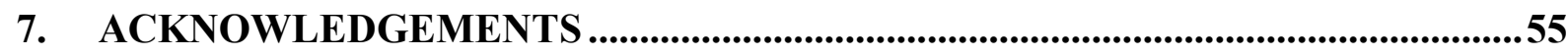

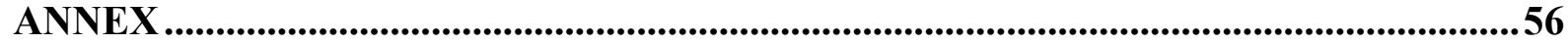




\section{INTRODUCTION}

Innate immunity relies on the detection of danger- and pathogen associated molecular patterns (DAMPs and PAMPs, respectively) and a prompt or quick response to maintain the homeostasis of the host. Several families of pattern-recognition receptor molecules (PRRs) [1] - including receptor for advanced glycation end products (RAGE), Toll-like receptor (TLR) family, Nod-like receptors (NLRs) and Rig-I-like receptors (RLRs) - are able to sense endogenous danger signals or invading pathogens [2]. Activation of these receptor molecules leads to a multistep cascade including nuclear factor- $\kappa \mathrm{B}(\mathrm{NF}-\kappa \mathrm{B})$, mitogen-activated protein kinases (MAPKs), and type I interferon (IFN) response resulting in production of mediators of inflammation and antimicrobial defense molecules and/or alarmins. Among the latters, different types of defensins can be regarded as the main effector antimicrobial proteins of the innate immune system [3].

Receptor for advanced glycation end products binds advanced glycation end products (AGEs), but also, a wide scale of endogenous alarmin molecules that are emerged from dying host cells into the extracellular spaces upon microorganism-induced or other type of cell damages. Besides AGEs among its ligands, ribonucleic and deoxyribonucleic acid (RNA and DNA) molecules, high mobility group box 1 protein (HMGB1), $\beta$-sheet fibrils and S100 proteins can be found [4]. Due to its broad spectrum of sensed molecular patterns, RAGE may contribute to the pathogenesis of several multifactorial diseases.

The NLR family has more than 20 members including nucleotide-binding oligomerization domain containing protein 1 and 2 (NOD1 and NOD2) [5]. These cytosolic receptors are essential in sensing intracellular microbial components, such as various peptidoglycan fragments of bacteria. Any impairment in function of NOD receptors may lead to an increased risk of infection, or an inappropriate mucosal defense mechanism.

Activation of pattern recognition receptors in various epithelial cells induces antibacterial responses. The sufficient defensin production are crucial in maintaining effective antibacterial defense of mucosal surfaces. Any impairment of these factors leads to a decreased antimicrobial potential, that are significant not only in diseases with infectious origin, but also in the pathogenesis of multifactorial diseases [6]. 


\subsection{THE FUNCTION OF RAGE}

The receptor for advanced glycation end products is a member of immunoglobulin superfamily of cell surface molecules $[7,8]$. The RAGE is much more than its name implies: it has a broad repertoire of ligands, which accumulate in the tissues during aging, chronic degeneration, inflammation, and the host response (Figure 1.).

Figure 1. Broad spectrum of RAGE ligands [4]

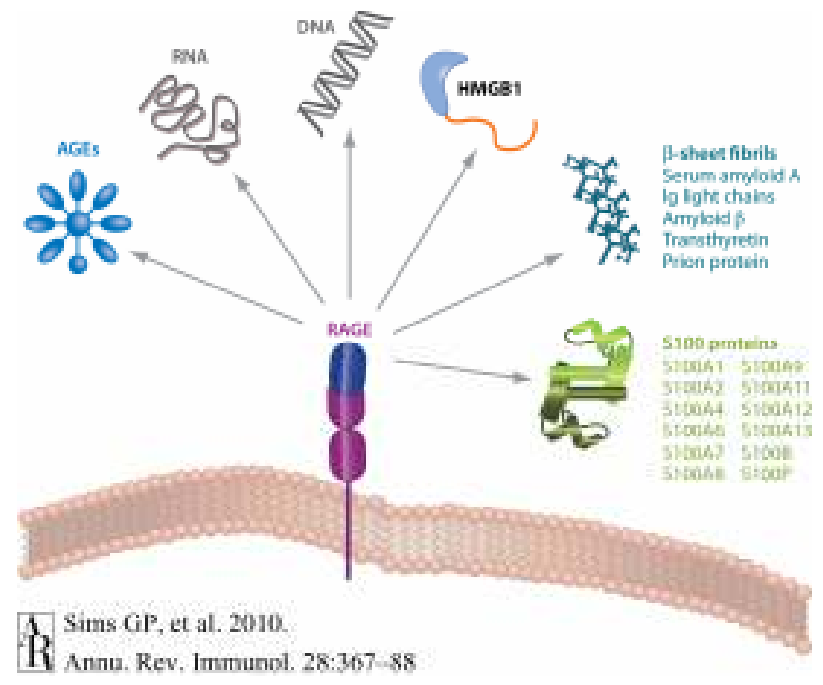

Besides the advanced glycation end products, it binds amyloid $\beta$-peptide (which accumulates in Alzheimer's disease) and amyloid A (which accumulates in systemic amyloidosis), the S100 proteins/calgranulins, (a family of closely related calcium-binding polypeptides that accumulate extracellularly at sites of chronic inflammation), amphoterin, and Mac-1 [9, $10,11,8]$. RAGE is expressed by a variety of cell types, including endothelial cells, smooth muscle cells, mononuclear phagocytes, astrocytes, neurons, and oligodendrocytes [12]. RAGE has been reported to be expressed in particular populations of cortical neurons, in the hippocampus, in spinal motor neurons of the anterior horn (especially Nissl bodies), in the ependyma and in the microvasculature of the brain. In addition, some peripheral nerves seem to express RAGE [13]. The ligand/RAGE interactions and the resulting RAGE upregulation are believed to activate many cell signaling pathways, leading to enhanced production of reactive oxygen species (ROS) and proinflammatory cytokines $[14,15,16]$.

The detrimental effects on tissues mediated via RAGE are caused by generation of oxidative stress and the up-regulation of inflammatory pathways followed by tissue injury. A number of studies have suggested that expression of RAGE is increased at the sites of ligand accumulation such as diabetic atherosclerotic lesions, Alzheimer disease, Creutzfeldt-Jacob disease, and Huntington disease [9, 17, 18, 19, 20, 8].

The gene for RAGE, AGER is located on chromosome 6p21.3, and at least 30 polymorphisms have been identified to date. Most of the polymorphisms are rare coding changes or located in non-coding regions, including introns and the 5'-flanking region [21]. Three single nucleotide polymorphisms (SNPs) have been highlighted including two common functional SNPs $(-429 \mathrm{~T} / \mathrm{C}$ [rs1800625] and -374T/A [rs1800624]) in the promoter region 
and a common coding change of a glycine to serine at amino acid 82 (G82S or Gly82Ser [rs2070600]). The $-429 \mathrm{~T} / \mathrm{C}$ and $-374 \mathrm{~T} / \mathrm{A}$ SNPs have been revealed to have effects on transcriptional activity [22]. The G82S SNP influences the AGE-binding domain [23], and the RAGE 82S allele up-regulates the binding of S100/calgranulins. The expression of RAGE is increased in neurodegenerative diseases [12], therefore we investigated the relevance of SNPs of RAGE promoter in the risk of multiple sclerosis.

\subsection{BACTERIAL SENSING BY NOD-LIKE RECEPTORS}

Inflammation and immune responses are dependent on host recognition of invading pathogens (Figure 2.). The NOD-like receptors (NLRs) are a specialized group of

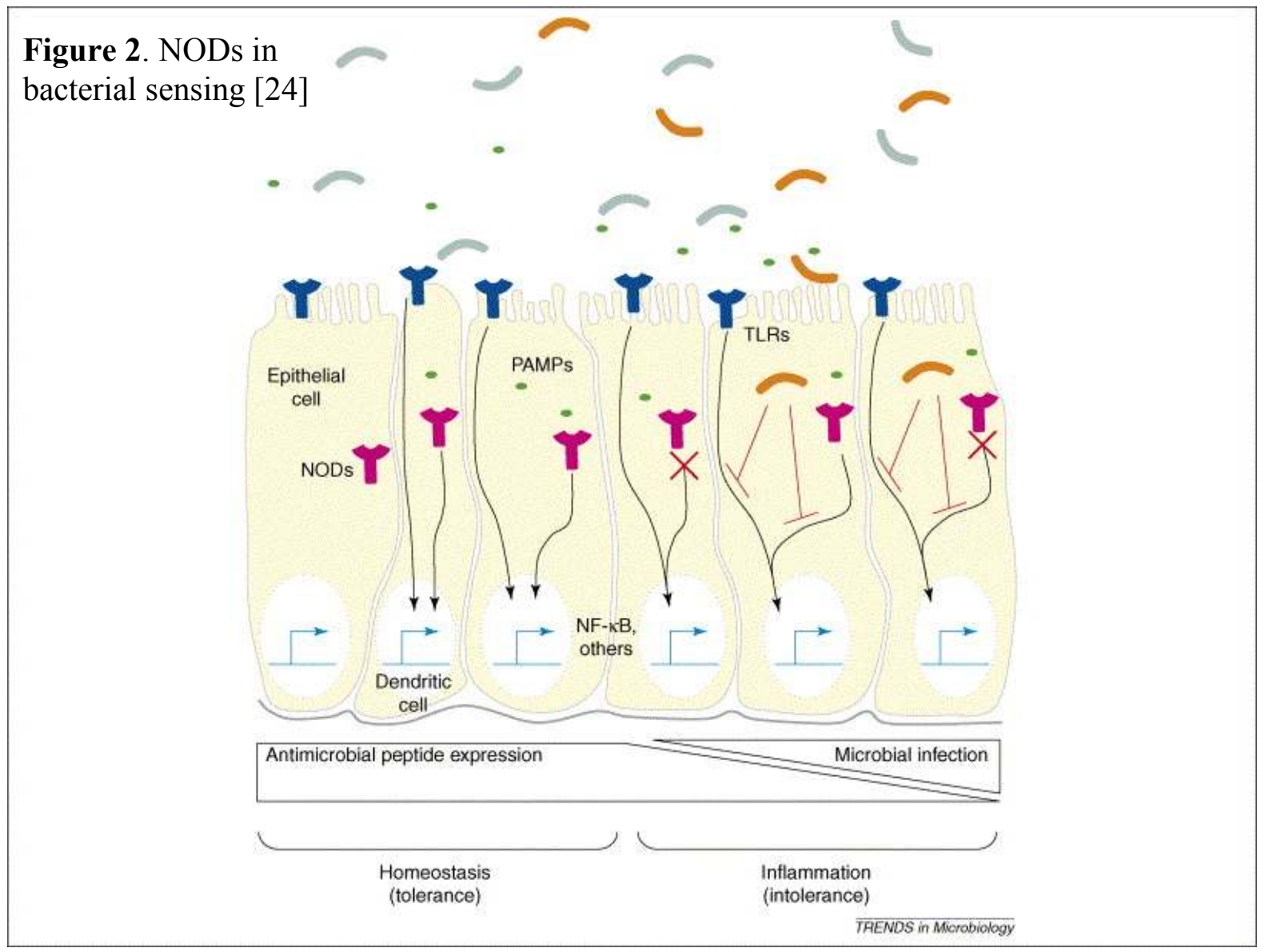

intracellular sensors that represent a key component of the host innate immune system [25]. NOD1 and NOD2 share three common domains. A carboxy terminal leucine rich repeat (LRR) has been shown to be responsible for detection of corresponding bacterial ligands. Interestingly, an extracellular LRR domain is also responsible for PAMP recognition in the case of TLRs, the ligand specificity of which, is defined by small amino acid insertions into the basic scaffold shared by each member [26]. A central NOD mediates self-oligomerization between molecules. The amino terminal caspase activation and recruitment domain (CARD) one in the case of NOD1 and two in the case of NOD2 - allows for protein-protein 
interaction, through self-recognition, and is responsible for the effector function of NLRs. NOD1 is ubiquitously expressed in various cell types, including epithelial cells, antigen presenting cells, human gingival fibroblasts, myofibroblasts, astrocytes and microglia.

NOD1 is activated by peptides that contain D- $\gamma$-Glu-meso-diaminopimelic acid (iEDAP) that is derived from peptidoglycan present in almost all gram-negative bacteria, and is produced either during synthesis and/or degradation [27]. By contrast, NOD2 recognizes muramyl dipeptides, also derived from peptidoglycan, but present in a much wider number of bacteria. Whilst NOD1 participates in the response to Chlamydia, Shigella, enteroinvasive Escherichia coli and Campylobacter, NOD2 has been shown to be activated by Mycobacterium tuberculosis, Salmonella, Listeria and Streptococcus [28].

The c.796G $>$ A polymorphism of NOD1 (rs2075820) has been described [29]; it encodes a changed protein, altering a glutamic acid residue (E), where the A allele corresponds to the $\mathrm{K}$ variation-lysine (E266K). In view of the close relation between NOD1 activation and Chlamydia infection, we considered it of interest to investigate the genetic polymorphism of NOD1 from the aspect of the development of stroke. The hypothesis of the study was, that the genetic polymorphism of NOD1 in an interaction with Chlamydophila pneumoniae infection might be a risk factor of stroke.

\subsection{HuMAN BeTA DEFENSINS}

Antimicrobial peptides (AMPs) are key components of innate immunity. Defensins are a family of antimicrobial peptides [3]. Whereas human $\alpha$-defensins HNP1-4 are expressed in neutrophils and HD-5 and HD-6 are physiologically confined to the Paneth cells of the small intestine, the second major family of defensins (ß-defensins) is apparently expressed in epithelial cells of the skin, gut, respiratory and urogenital tissue [30]. While human betadefensin 1 (HBD-1) is produced constitutively, HBD-2 is induced by interleukin-1ß (IL-1 $\beta$ ), tumor necrosis factor- $\alpha$ (TNF- $\alpha$ ) and bacterial lipopolysaccharide (LPS), and by contact with Gram-negative (Escherichia coli, Pseudomonas aeruginosa) and Gram-positive (Staphylococcus aureus) bacteria, and the yeast Candida albicans [31]. Moreover it is induced in a protein kinase C-dependent manner by Malassezia furfur [32]. Thus, HBD-2 levels are increased in inflammatory disorders, whereas HBD-1, being constitutively expressed, may serve as a defense in the absence of inflammation [33].

Epithelial-derived human $\beta$-defensins, important components of host defense at the mucosal surfaces, display a broad spectrum of activity against bacteria, fungi and viruses, and also exhibit other functions, including potent chemotactic activity toward immature dendritic 
cells and memory T cells [34]. To date, a total of $28 ß$-defensin genes have been identified in the human genome; located in five clusters. The cluster on chromosome 8p22-23 contains eight $\beta$-defensins (HBD-1 to HBD-4 and DEFB105 to DEFB108) known to date [35]. While HBD-1, HBD-3 and HBD-4 appear to be constitutively expressed on intestinal epithelial cells, HBD-2 is upregulated only during the course of inflammation. It is noteworthy that HBD-1 mRNA expression has also been detected in pancreatic acinar cells [36, 37]. Thus, HBD-1 could act in host defense in the pancreas. It is likely that the role of HBD-1 is to prevent the invasion of bacteria from the proximal small intestine. This marked expression of HBD-1 in the pancreas might be related to the protection of pancreatic epithelial cells from retrograde infection via the pancreatic duct, or it might contribute to the antimicrobial properties of pancreatic secretion.

HBD-1 is also constitutively expressed by leukocytes. Besides epithelial cells, the expression of HBD-2 has been observed in human monocytes, macrophages and dendritic cells [38]. Astrocytes may be another source of local HBD-2 synthesis in the brain [39]. The naturally synthesized antimicrobial peptides may protect the brain against bacterial or viral infection.

The DEFB1 gene, which encodes HBD-1, is located in region p23 on chromosome 8. HBD-1 expression varies among individuals, even though this peptide is considered to be constitutively expressed. Three frequent single nucleotide polymorphisms (SNPs) at positions $-20 \mathrm{G} / \mathrm{A}(\mathrm{rs} 11362),-44 \mathrm{C} / \mathrm{G}$ (rs1800972) and -52G/A (rs 1799946) in the 5'-untranslated region (UTR) of the DEFB1 gene were described by Dork and Stuhrmann [40]. These mutations are indicated as c. $-20 \mathrm{G}>$ A, c. $-44 \mathrm{C}>\mathrm{G}$ and c. $-52 \mathrm{G}>\mathrm{A}$, respectively, according to suggestions for mutation nomenclature [41]. The untranslated variants influence HBD-1 expression or function [42]. Variations in the DEFB1 gene have been associated with Pseudomonas aeruginosa airway colonization in cystic fibrosis [43]. Polymorphisms in the DEFB1 gene encoding HBD-1 have been linked with susceptibility to diseases, including chronic obstructive pulmonary disease and asthma [44, 45]. Kocsis et al. recently observed an association between DEFB1 SNPs and colonic localization of Crohn's disease [46].

Figure 3. Defensins in mucosal immunity [47]

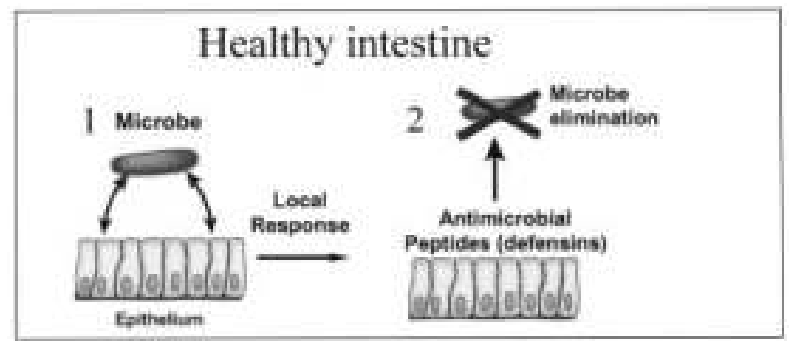

varies from individual to individual and it has been suggested that this variation is due to genetic differences in the genes encoding the HBDs. Two types of genetic 
polymorphisms have been identified in genes encoding defensins, copy number polymorphisms (or copy number variations, CNVs) and single nucleotide poymorphisms (SNPs). Hollox et al. [48] have described copy number polymorphisms of the DEFB4 gene, which encodes HBD-2, with copy numbers ranging from 2 to 12 per diploid genome. Higher DEFB4 copy numbers correlated with higher levels of DEFB4 mRNA expression. Accordingly, it is presumed that this polymorphism may be an important component of genetic variation in susceptibility to infections. Similar results have been published by Linzmeier and Ganz [49].

\subsection{ASSOCIATED DISEASES}

The adequate function of the components of the innate immunity is crucial in maintaining the homeostasis of the host. Genetic polymorphisms in the genes encoding PRRs and AMPs altering expressional level or subsequent amino acid sequence may impair their functions, and contribute to the pathogenesis of several multifactorial diseases. Examples of such diseases that were investigated in our studies are highlighted below.

\subsubsection{Multiple sclerosis and RAGE}

Multiple sclerosis (MS), a devastating neuroinflammatory disorder of the central nervous system, can be characterized by multiple demyelization foci of the central nervous system, which, in the course of the disease, can materialize in different time patterns: relapsing-remitting type (RR), secondary progressive (SP) type, or primary progressive (PP) type $[52,53,54]$. The main pathological features of the disease are the destruction of the myelin sheaths of the nerve fibers, the relative sparing of the axons, and the infiltration of inflammatory cells in a perivascular distribution. Although the well-defined autoimmune activities of the different types against the central nervous system are of great importance in the course of the disease, the pathomechanism and the direct causative factors have not yet been elucidated. There are data indicating that changes in the level of the ROS may play roles in the pathomechanism of MS. The disease is determined by a combination of exogenous factors and genetic background. Immunohistological studies of spinal cord tissue derived from MS patients have demonstrated enhanced RAGE expression in neurons and inflammatory cells [12].

\subsubsection{Acute ischemic stroke, Chlamydophila pneumoniae infection and NOD1}

Stroke is a major health problem worldwide and there is an urgent need for a better understanding of its causes and for the prevention of its occurrence. Stroke is divided broadly 
into ischemic and hemorrhagic stroke. Ischemic stroke is a frequent heterogeneous multifactorial disease that is affected by several environmental factors and genetic mutations. Classical modifiable risk factors include hypertension, cardiac disease, dyslipidemia and smoking. Evidence indicates that infections, inflammatory processes and modifiable risk factors interact with genetic factors to cause stroke [56, 57, 58, 59, 60, 61]. Ischemic stroke may be further divided into that caused by large vessel disease (because of atherosclerosis and plaque formation within the common and internal carotid arteries), that caused by small vessel disease (because of the involvement of small perforating end-arteries within the brain), and cardiogenic stroke (secondary to blood clots traveling from the heart) [57].

Chronic infections with certain pathogens, such as Chlamydophila pneumoniae, and genetic parameters that influence inflammatory reactions are suggested to contribute to the disease. Serological evidence of past infection with $C$. pneumoniae, a common respiratory pathogen, has been claimed to be associated with risk of ischemic stroke [62, 63, 64, 65, 66, 67]. However, in recent studies, data on the role of $C$. pneumoniae in patients with ischemic stroke are still inconstant $[68,69,70]$. The chronic infection of susceptible target cells, especially monocytes and endothelial cells, initiates local inflammation, which is important in plaque formation. Chlamydiae induce chronic activation of the immune system, but little is known about the mechanisms of $C$. pneumoniae-induced target cell alterations.

The cytosolic NOD proteins are molecules that have been implicated in intracellular pattern recognition of bacteria such as the obligate intracellular Chlamydia [70, 71, 72, 73, $74]$ in addition to their primary role in host defense against invading pathogens, their ability to regulate NF- $\kappa B$, signaling, IL-1ß production, and cell death indicates that they are crucial to the pathogenesis of a variety of inflammatory human diseases [75]. NF-kB activation via NOD1 is crucial in maintaining inflammatory responses and cytokine activation [76]. It is also known that the activation of NOD receptors mediates the induction of human betadefensins in various epithelial cells [77]. NOD1-mediated endothelial cell activation by Chlamydophila. pneumoniae was recently demonstrated [78]; therefore, it appears that NOD1 is a potent innate immune receptor for C. pneumoniae in endothelial cells and monocytes.

\subsubsection{Acute pancreatitis}

Acute pancreatitis (AP) is a disease with a wide spectrum of clinical courses, ranging from mild to severe forms, with a high rate of complications and a high risk of lethality. Severe AP (SAP) is characterized by various degrees of necrosis of the pancreatic 
parenchyma and by local and systemic complications, such as the systemic inflammation response syndrome and multiple organ failure.

Bacterial contamination of pancreatic necrosis and the ensuing sepsis are the main causes of death in SAP [79] facilitated by gut barrier dysfunction and increased intestinal permeability resulting in bacterial translocation through the gut wall [80]. The permeability of the gastrointestinal mucosa increases during the early phase of SAP and enables bacterial/endotoxin translocation [81, 82]. The gut barrier plays an important role in AP; in fact, gut barrier integrity prevents bacterial translocation resulting from an atrophic and leaky gut, and decreases the systemic inflammatory response in pancreatitis from gut atrophy. Pancreatic stellate cells are able to recognize pathogen-associated molecular patterns via their receptors, leading to the activation of signaling pathways and proinflammatory responses [83]. Thus, pancreatic stellate cells might play a role in immune function of the pancreas through the recognition of pathogen-associated molecular patterns. The intestinal epithelium forms a relatively impermeable barrier between the lumen and the submucosa. This barrier function is maintained by a complex of proteins. The innate immune system plays a crucial role in maintaining the integrity of the intestine. Mucosal epithelial cells produce a variety of antimicrobial peptides that protect the mucosal surface against invading microbes [84]. Which is certainly important in preventing the bacterial translocation in the case of mild pancreatitis. There is evidence that host genetic factors can affect the severity of AP. Genes coding for inflammatory cytokines have been reported to act as modifier genes in AP [50, 51].

\subsection{DEFENSIN INDUCTION BY CHLAMYDOPHILA PNEUMONIAE}

Chlamydophila pneumoniae, an obligate intracellular parasite and a common cause of acute respiratory infection, has a tendency to cause persistent inflammatory diseases such as atherosclerosis, which may lead to cardiovascular disease or stroke $[85,63,66]$. Three principle cell types involved in the atherogenic process within the developing atheroma include endothelial cells, vascular smooth muscle cells, and monocytes/macrophages. Recent publications have indicated that $C$. pneumoniae infection induces HBD-2 expression in human mononuclear cells and in gingival fibroblasts [86, 87].

It has been reported that $C$. pneumoniae can infect human endothelial cells and induce the expression of cytokines, adhesion molecules, chemokines and molecules with procoagulant activity [88]. As endothelial cells are related to the physiopathology of stroke [89], we considered it of interest to investigate the effects of in vitro C. pneumoniae infection on the HBD-2 expression in brain capillary endothelial cells. 


\section{AIMS}

The genetic variations of pattern recognition receptor molecules and defensins may influence the severity and/or the course of multifactorial diseases, such as multiple sclerosis, stroke and pancreatitis. Therefore we investigated:

- Three common genetic polymorphisms of RAGE in patients with multiple sclerosis;

- The c.796G $>$ A SNP of NOD1 gene was investigated from the aspect of the development of ischemic stroke;

- The relevance of three SNPs in the promoter region of DEFB1, that might be related to the development of SAP or to bacterial contamination of pancreatic necrosis, was investigated. Accordingly, the copy number variation of DEFB4 gene, that alters the level of produced HBD-2 peptide, was studied among patients with acute pancreatitis;

- As endothelial cells are related to the physiopathology of stroke, we completed our studies with the investigation of the effects of in vitro infection with Chlamydophila pneumoniae on the expression of human beta-defensin 2 in human brain capillary endothelial cells. 


\section{PATIENTS AND METHODS}

\subsection{PATIENTS AND CONTROLS}

All patients and control subjects gave informed consent to their participation in our studies, and the local ethics committees - Human Investigation Review Board at the University of Szeged, Albert Szent-Györgyi Medical and Pharmaceutical Center, Szeged, Hungary and the Human Investigation Review Board of Pándy Kálmán Hospital, Gyula, Hungary - likewise gave their prior approval to the studies. All cases and controls were of Hungarian ethnic origin and resident in Hungary.

\subsubsection{Patient group with multiple sclerosis and controls}

The study population comprised 154 relapsing-remitting (RR) and 14 secondary progressive (SP) type MS patients with a mean age of $42.1 \pm 8.5$ years. The patients were diagnosed and recruited from the Department of Neurology at the University of Szeged and Department of Neurology of Pándy County Hospital in Gyula. The clinical inclusion criterion was a diagnosis of clinically definitive MS (Poser criteria [52]). The RR form was defined as the occurrence of exacerbations followed by complete or partial remissions. The SP course was defined as the occurrence of a slow worsening of the disability lasting for more than 6 months, without or with relapses, in subjects who, before the progressive phase, had exhibited an RR course (Poser et al. 1983). The clinical diagnosis was supported by the MRI criteria $[90,91]$. The expanded disability status scale score [92] for the patients ranged from 0 to 8 (mean, $2.81 \pm 1.4$ ) with a disease duration of less than $1-20$ years (mean, $8.3 \pm 4.5$ years).

The control group consisted of 136 age- and gender matched healthy blood donors.

\subsubsection{Patient group with acute ischemic stroke and controls}

A total of 280 patients with acutely developing ischemic stroke, who had never suffered a previous stroke event, were involved in the study. The study design was prospective; these were consecutive patients. The patients were characterized and were enrolled into one of the following stroke groups immediately after the clinical neurological and MRI examinations. The first group represented the 'large-vessel group' corresponded to large-vessel infarction. The second group corresponded to the 'small-vessel occlusion type', which was defined as one or more small subcortical hemispheric or brainstem infarcts. The third group corresponded to a mixed vascular pathology - one or more lacunar and largevessel infarcts on the MRIs. This classification, based on the clinical and clearly defined radiological features, was considered to be the most exact and quantifiable method with 
regard to the requirement that the subgroups have to reflect the main well-defined vascular pathologies. All sera from ischemic stroke patients (from either patients or controls) were tested for Chlamydophila pneumoniae IgG by serology with a commercial ELISA kit (NovaTec Immundiagnostica GmbH, Dietzenbach, Germany) according to the instructions of the manufacturer. The samples were considered positive if the absorbance value was higher that $10 \%$ over the cut-off value.

The control group consisted of 150 age- and gender matched healthy blood donors.

\subsubsection{Patient group with acute pancreatitis and controls}

One-hundred and twenty-four patients with acute pancreatitis were enrolled in our study (75 men and 49 women, age $58 \pm 6.9$ years). Thirty of them suffered from the mild and 94 from the severe form of the disease, classified according to the original criteria of Ranson [93]. The criteria for the diagnosis of acute pancreatitis were a clinical history consistent with the disease, appropriate radiological evidence, and serum amylase level higher than $660 \mathrm{U} / \mathrm{L}$. All patients were classified as having mild AP (patients with $<3$ positive signs; $n=30$ ) or SAP (patients with $\geq 3$ positive prognostic signs; $n=94$ ) according to the criteria of Ranson [93]. Among the patients with necrotizing SAP, the diagnosis of infected pancreatic necrosis $(n=29)$ was based on bacterial cultures of the necrotic pancreatic tissue sampled during surgery or US- or CT-guided biopsies. In 88 patients, the AP was caused by alcohol $(>80$ $\mathrm{g} /$ day), in 20 the cause was cholelithiasis, in 10 cases pancreatitis developed following endoscopic retrograde cholangiopancreatography (ERCP), and in 6 patients no cause could be identified (these cases were classified as idiopathic). Patients were enrolled in this prospective study at the Department of Surgery and the Department of Internal Medicine of Albert SzentGyörgyi Medical Center of Szeged University between September 2007 to May 2009.

The control cohort consisted of random, unrelated population of 100 healthy blood donors. Control subjects did not have any gastrointestinal and/or liver diseases and were selected from consecutive blood donors in Szeged.

\subsection{GENOTYPING PROCEDURES}

\subsubsection{DNA extraction}

For the detection of various SNPs and CNVs genomic DNA was purified from peripheral whole blood. The leukocyte DNA was isolated according to the manufacturer's instructions. (High Pure PCR Template Preparation Kit, Roche Diagnostic GmbH, Mannheim, Germany). DNA concentration was measured by Qubit fluorometer (Invitrogen, Carlsbad, USA). The genomic DNA was stored at $-20^{\circ} \mathrm{C}$ until further use. 


\subsubsection{Determination of RAGE SNPs}

Restriction fragment length polymorphism (RFLP) assays were used to detect the -429T/C (rs 1800625), -374T/A (rs1800624), and the G82S (rs2070600) SNPs of RAGE. For amplification of the region containing the $-374 \mathrm{~T} / \mathrm{A}$ and $-429 \mathrm{~T} / \mathrm{C}$ polymorphisms, the following primers were used: sense primer, 5'-TCAGAGCCCCCGATCCTATTT-3'; antisense primer, 5'-GGGGGCAGTTCTCTCCTC-3'. PCR amplification was performed in a $25-\mu 1$ reaction volume containing 25 pmol of forward and reverse primer, $100 \mathrm{ng}$ of template DNA, $200 \mu \mathrm{mol} / 1$ of each dNTP, $1.5 \mathrm{mmol} / 1 \mathrm{MgCl}_{2}, 1 \mathrm{U}$ Taq polymerase (Fermentas, Vilnius, Lithuania), and a reaction buffer containing $75 \mathrm{mmol} / 1$ Tris- $\mathrm{HCl}, 20 \mathrm{mmol} / \mathrm{l}\left(\mathrm{NH}_{4}\right)_{2} \mathrm{SO}_{4}$, $0.01 \%$ Tween. The conditions of amplification were as follows: $94^{\circ} \mathrm{C}$ for $5 \mathrm{~min}$ and $94^{\circ} \mathrm{C}$ for $30 \mathrm{~s}, 57^{\circ} \mathrm{C}$ for $30 \mathrm{~s}$, and $72^{\circ} \mathrm{C}$ for $60 \mathrm{~s}$ for a total of 30 cycles, and finally $7 \mathrm{~min}$ at $72^{\circ} \mathrm{C}$. The PCR product $(20 \mu \mathrm{l})$ was then digested with AluI (Fermentas; $5 \mathrm{U}$ for $16 \mathrm{~h}$ at $37^{\circ} \mathrm{C}$ ) for $-429 \mathrm{~T} / \mathrm{C}$ and with TasI (Fermentas; $5 \mathrm{U}$ for $16 \mathrm{~h}$ at $65^{\circ} \mathrm{C}$ ) for $-374 \mathrm{~T} / \mathrm{A}$. The restriction products were separated by electrophoresis in 3\% agarose gels and visualized in UV light after gel red staining. The fragment lengths are listed in Figure 4.

Figure 4. RFLP genotyping of the $-429 \mathrm{~T} / \mathrm{C}$ and $-374 \mathrm{~T} / \mathrm{A}$ polymorphisms. Lanes 2 , 3, and 4

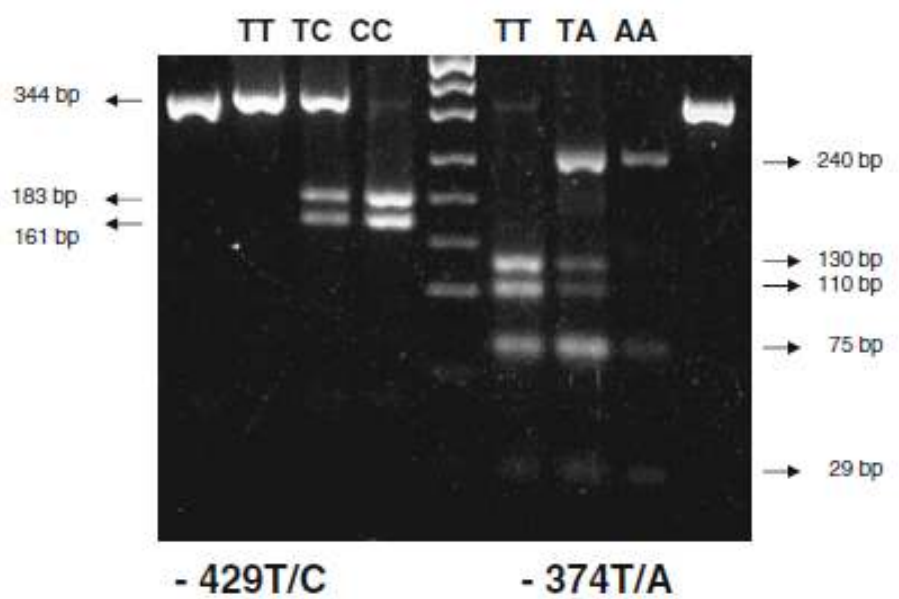
correspond to genotypes TT (344 bp), TC (344, 183, and $161 \mathrm{bp})$ and CC (183 and $161 \mathrm{bp}$ ) for $-429 \mathrm{~T} / \mathrm{C}$; lanes 6,7 , and 8 correspond to genotypes TT $(130,110,75$ and 29 bp), TA (240, 130, 110, 75, and $29 \mathrm{bp})$, and AA $(240,75$, and 29 bp). For $-374 \mathrm{~T} / \mathrm{A}$, lanes 1 and 9 represent undigested PCR products, lane 5 depicts a MW marker

Genotypes were scored according to the patterns of DNA bands (Figure 4.). The G82S polymorphism in exon 3 of the RAGE gene was detected by RFLP [23]. Briefly, for amplification, the following primers were used: sense primer, 5'GTAAGCGGGGCTCCTGTTGCA-3', and antisense primer, 5'GGCCAAGGCTGGGGTTGAAGG-3'. PCR was performed as follows: $94^{\circ} \mathrm{C}$ for $5 \mathrm{~min}$; $94^{\circ} \mathrm{C}$ for $30 \mathrm{~s}, 62^{\circ} \mathrm{C}$ for $45 \mathrm{~s}$, and $72^{\circ} \mathrm{C}$ for $60 \mathrm{~s}$, for a total of 35 cycles, and finally $7 \mathrm{~min}$ at $72^{\circ} \mathrm{C}$. PCR product was digested with AluI (Fermentas), $3 \mathrm{U}$ for $16 \mathrm{~h}$ at $37^{\circ} \mathrm{C}$, followed by electrophoresis on $12 \%$ acrylamide gels. The digestion provided fragments of 248,123 , and 
26 bp lengths for GG homozygotes and 248, 181, 123, 67, and 26 bp length for SG heterozygotes (SS homzygotes should display four bands, reflecting fragment lengths of 181, 123,67 , and 26 bp, but no SS genotypes were detected in our study.)

\subsubsection{Determination of $\mathrm{c} .796 \mathrm{G}>\mathrm{A}$ polymorphism of NOD1}

The 796G-to-A transition in exon 3 was analyzed by PCR-RFLP [29]. The reaction mixture of $50 \mu \mathrm{l}$ contained $100 \mathrm{ng}$ of genomic DNA, 20 pmol of each primer (sense: 5'TGAGACCATCTTCATCCTGG-3'; antisense: 5'-CTTCCCACTGAGCAGGTTG-3'), 1.25 U Taq DNA polymerase (Fermentas, Vilnius, Lithuania), $1.5 \mathrm{mM} \mathrm{MgCl}, 1 \times \mathrm{PCR}_{2}$ Taq polymerase buffer $+\left(\mathrm{NH}_{4}\right)_{2} \mathrm{SO}_{4}$, and $25 \mathrm{mM}$ of each dNTP (Fermentas). After denaturation $\left(12 \mathrm{~min}\right.$ at $\left.95^{\circ} \mathrm{C}\right)$, the reaction consisted of $30 \mathrm{PCR}$ cycles $\left(30 \mathrm{~s}\right.$ at $94^{\circ} \mathrm{C}, 30 \mathrm{~s}$ at $58^{\circ} \mathrm{C}$, and 30 $\mathrm{s}$ at $72^{\circ} \mathrm{C}$ ) followed by a final extension of $7 \mathrm{~min}$ at $72^{\circ} \mathrm{C}$. For RFLP analysis the PCR products were digested with AvaI restriction enzyme (Fermentas) at $37^{\circ} \mathrm{C}$ overnight, electrophoresed on 2\% agarose gel (Sigma-Aldrich, St Louis, MO, USA), visualized under UV illumination and stained with $0.4 \mathrm{mg} / \mathrm{l}$ ethidium-bromide. The presence of a AvaI site (G allele) was indicated by cleavage of the $379 \mathrm{bp}$ amplified PCR product to yield fragments of 209 and $170 \mathrm{bp}$.

\subsubsection{Determination of DEFB1 SNPs}

Genotyping was performed using Custom TaqMan ${ }^{\circledR}$ SNP Genotyping Assays (Applied Biosystems, USA). Fluorogenic minor groove binder probes were used for each cases using the dyes 6-carboxyfluorescein (FAM; excitation, $494 \mathrm{~nm}$ ) and VIC (excitation, $538 \mathrm{~nm}$ ): beta-defensin-1 polymorphisms c.-20G $>$ A (rs11362), c.-44C $>$ G (rs1800972) and c.-52G $>$ A (rs1799946). Thermal cycling was performed on ABI Prism 7000 sequencedetection PCR systems. The amplification mix contains the following ingredients: $7.5 \mu \mathrm{l}$ of $\mathrm{TaqMan}^{\circledR}$ universal PCR master mix (Applied Biosystems), $0.375 \mu \mathrm{l}$ of primer-probe mix, $6.375 \mu \mathrm{l}$ of RNase- and DNase-free water (Sigma), and $0.8 \mu \mathrm{l}$ of sample DNA, in a total volume of $15 \mu \mathrm{l}$ per single tube reaction. Assay conditions were $2 \mathrm{~min}$ at $50^{\circ} \mathrm{C}, 10 \mathrm{~min}$ at $95^{\circ} \mathrm{C}$, and 40 cycles of $95^{\circ} \mathrm{C}$ for $15 \mathrm{~s}$ and $60^{\circ} \mathrm{C}$ for $1 \mathrm{~min}$. Each 96 -well plate contained 94 samples of an unknown genotype and two reactions with reagents but no DNA (non-template control). Initial and post-assay analysis was performed using the Sequence Detection System (SDS) version 2.1 software (Applied Biosystems) as outlined in the TaqMan Allelic Discrimination Guide. Genotypes were determined visually based on the dye-component fluorescent emission data depicted in the X-Y scatter plot of the SDS software. Genotypes were also determined automatically by the signal processing algorithms in the software. 
Results of each scoring method were saved in two separate output files for later comparison. In order to verify the given data, restriction fragment length polymorphism analysis was performed in 50 cases of all the 3 mutations as described previously by Wallace et al. [94]. The TaqMan ${ }^{\circledR}$ assays and the RFLP methods yielded identical results.

\subsubsection{Determination of DEFB4 gene copy number}

A TaqMan ${ }^{\circledR}$ real-time PCR assay, specifically for amplification of genomic DEFB4, was established by using a specific set of amplification primers (forward 5'TGAAGCTCCCAGCCATCAG-3'; reverse 5'-TATTTCCCTGGCCCATCTCA-3' and a VIC-labeled probe (5'-VIC-ATCTCCTCTTCTCGTTCC-MGB-3'). Quantitative DEFB4 amplification data were normalized to ALB (FAM-labeled albumin, Applied Biosystems) as an internal reference gene, which was co-amplified simultaneously in a single tube biplex assay. The primers and probe for DEFB4 were designed using Primer Express 3.0 (Applied Biosystems). Primers were purchased from Biocenter (Szeged, Hungary) and probes were obtained from Applied Biosystems. Real-time PCR was performed using the ABI Prism 7000 SDS. Amplification reactions (15 $\mu \mathrm{l}$ each) were performed in triplicate with $20 \mathrm{ng}$ of template DNA, Maxima ${ }^{\mathrm{TM}}$ Probe qPCR Master Mix 2× (Fermentas, Vilnius, Lithuania), $300 \mathrm{nM}$ of each primer, and $200 \mathrm{nM}$ of each fluorogenic probe. Thermal cycling was initiated with a 10min incubation at $95^{\circ} \mathrm{C}$ to denature genomic DNA and to activate Fermentas polymerase. This was followed by 40 cycles of two steps of $95^{\circ} \mathrm{C}$ for $15 \mathrm{sec}$ and $60^{\circ} \mathrm{C}$ for 1 minute, the fluorescence intensity was measured during the step of $60^{\circ} \mathrm{C}$. In each assay, a standard curve was recorded and a no-template control was included. To amplify DEFB4 and albumin in a one-tube biplex assay, limiting primer conditions were identified, to avoid competition of the two reactions. Quantification was performed by the comparative threshold cycle $\left(\mathrm{C}_{\mathrm{T}}\right)$ method, as described previously [95].

\subsection{IN VITRO STUDIES}

\subsubsection{Cell line and in vitro infection with Chlamydophila pneumoniae}

BB19 cells, human brain capillary endothelial cells immortalized with the E6E7 genes of human papilloma virus [96] were kindly provided by Dr J. Nelson (Department of Microbiology and Immunology, Oregon Health Sciences University, USA). The cell line was cultured as monolayer culture (cell culture medium RPMI supplemented with 10\% FCS and $10 \%$ human $\mathrm{AB}$ serum, and $50 \mathrm{mg} / \mathrm{ml}$ endothelial growth factor [Sigma]). Cells were seeded onto culture surface precoated with $1 \%$ gelatine at a density of $100,000-150,000$ cells $/ \mathrm{ml}$. 
Chlamydophila pneumoniae CWL-029 respiratory strain, obtained from ATCC, and C. pneumoniae CV6 cardiovascular strain, isolated from an atheroma of a patient with coronary artery disease [97], were propagated in Hep2 cells. Infected cells were harvested on day 3 or 4 and then disrupted by two cycles of freeze-thawing and ultrasonication. Cell debris was removed by centrifugation at $300 \mathrm{~g}$ for $10 \mathrm{~min}$, and bacteria were concentrated by centrifugation at $30,000 \mathrm{~g}$ for $30 \mathrm{~min}$. Pellets were resuspended in sucrose-phosphateglutamic acid buffer. For mock infection, uninfected Hep2 cells were processed as described above. BB19 cells were transferred to 6 -well plates at a density of $1 \times 10^{6}$ cells/well, and infected with C. pneumoniae stock at a multiplicity of infection (MOI) of 5 IFU/cell. Control cells were not infected, or were treated with the same volume of mock stock. In addition to infection with viable $C$. pneumoniae, BB19 cells were stimulated with organisms that had been previously heat-inactivated (at $70^{\circ} \mathrm{C}$ for $45 \mathrm{~min}$ ). Inoculated cells were centrifuged at $800 \mathrm{~g}$ for $60 \mathrm{~min}$ at room temperature $\left(20-22^{\circ} \mathrm{C}\right)$. Medium was then changed for fresh medium without cycloheximide. The plates were incubated at $37^{\circ} \mathrm{C}$ under $5 \% \mathrm{CO}_{2}$, and infected and control cells were harvested at the times indicated.

\subsubsection{RNA isolation from BB-19 cell lysates and PCR amplification}

Total RNA was isolated with Perfect RNA Eukaryotic Mini kit (Eppendorf) according to the manufacturer's instructions. The RNA concentration was determined by the $A_{260}$ value of the sample. Complementary DNA (cDNA) was generated from $1 \mathrm{mg}$ total RNA using the High-Capacity cDNA Reverse Transcription Kit (Applied Biosystems) in a final volume of 20 $\mu 1$. After reverse transcription Real-time PCR analyses were performed in a fluorescence temperature cycler (LightCycler; Roche Diagnostics GmbH, Mannheim, Germany) according to the manufacturer's instructions. Samples were loaded into capillary tubes and placed in the fluorescence thermocycler (LightCycler). Initial denaturation at $95^{\circ} \mathrm{C}$ for $10 \mathrm{~min}$ was followed by 55 cycles of $95^{\circ} \mathrm{C}$ for $5 \mathrm{~s}$, the primer specific annealing temperature for $10 \mathrm{~s}$, and elongation at $72^{\circ} \mathrm{C}$ for $10 \mathrm{~s}$. For HBD-2 (sense, 5'-ATCAGCCATGAGGGTCTTGT-3'; antisense, 5'-GAGACCACAGGTGCCAATTT-3'), the annealing temperature was set to $62^{\circ} \mathrm{C}$. For HBD1- (sense, 5'-TTGTCTGAGATGGCCTCAGGTGGTAAC-3'; antisense, 5'ATACTTCAAAAGCAATTTTCCTTTAT-3', the annealing temperature was set at $58^{\circ} \mathrm{C}$. Initial denaturation at $95^{\circ} \mathrm{C}$ for $10 \mathrm{~min}$ was followed by 50 cycles of $95^{\circ} \mathrm{C}$ for $10 \mathrm{~s}$, the primer-specific annealing temperature for $7 \mathrm{~s}$, and elongation at $72^{\circ} \mathrm{C}$ for $12 \mathrm{~s}$. For the housekeeping gene GAPDH (glyceraldehyde-3-phosphate dehydrogenase); sense, 5'AAGGTCGGAGTCAACGGATTT-3'; antisense, 5'-TGGAAGATGGTGATGGGATTT-3' 
primers were used. At the end of each run, melting-curve profiles were achieved by cooling the sample to $40^{\circ} \mathrm{C}$ for $15 \mathrm{~s}$ and then heating the sample slowly at $0.20^{\circ} \mathrm{C} / \mathrm{s}$ up to $95^{\circ} \mathrm{C}$ with continuous measurement of the fluorescence to confirm the amplification of specific transcripts. Cycle-to-cycle fluorescence emission readings were monitored and analyzed using LightCycler software (Roche Diagnostics). Total RNA samples without reverse transcription were amplified in the same way in order to exclude the possibility of the DNA contamination of the RNA preparations. The amount of RNA was equivalent to that added to the reaction via the reverse transcription reaction. Real-time PCR reaction and the melting point analysis were performed and the results were negative. All quantifications were normalized to the housekeeping GAPDH gene. Relative gene expression is given as a ratio between target gene and GAPDH gene expressions.

\subsubsection{Western blot assays}

BB-19 cells were homogenized in ice-cold lysis buffer containing RIPA buffer and protease inhibitor cocktail (Sigma), and the mixture was then centrifuged at 10,000 $\mathrm{g}$ for 10 min to remove cell debris. Protein concentrations of cell lysates were determined using the Bio-Rad protein assay (Bio-Rad, Hercules, CA, USA). Supernatants were mixed with Laemmli's sample buffer and boiled for $3 \mathrm{~min}$. To detect beta-defensin, aliquots of the supernatants containing $25 \mathrm{mg}$ of total protein were resolved by SDS-PAGE and electrotransferred onto polyvinylidene difluoride membranes (Bio-Rad). Preblocked blots were reacted for $4 \mathrm{~h}$ with specific polyclonal antibodies to human beta-defensin 2 (RD Systems, Minneapolis, MN, USA) in PBS containing 0.05\% (v/v) Tween-20, 1\% (w/v) dried non-fat milk (Difco Laboratories, Detroit, MI, USA) and 1\% (w/v) BSA (fraction V; Sigma). Blots were then incubated for $2 \mathrm{~h}$ with species-specific secondary antibody coupled to peroxidase (peroxidase-conjugated anti-goat antibody[Sigma]). Filters were washed five times in PBS-Tween for 5 min after each step and were developed using a chemiluminescence detection system (Amersham, Buckinghamshire, UK).

\subsubsection{Human B-defensin 2 ELISA}

For direct testing of the presence of the HBD-2 peptide in the infected and uninfected brain capillary endothelial cells, and for measurement of the secreted HBD-2 protein into the tissue culture medium, a sensitive HBD-2 ELISA (Alpha Diagnostic, San Antonio, TX, USA) was used according to the manufacturer's instructions. The detection limit of this ELISA kit was $0.8 \mathrm{pg}$ HBD-2 protein $/ \mathrm{ml}$. 


\subsubsection{Immunofluorescent assay}

Expression of HBD-2 peptide by Chlamydophila pneumoniae infected and noninfected BB19 cells in Cytospin preparations were investigated by immunofluorescence analysis. Cells were fixed in $1 \%$ acetone for $15 \mathrm{~min}$ at room temperature. Cells were stained with goat anti-HBD-2 antibody (RD Systems) for $1 \mathrm{~h}$. Bound antibody was detected with FITC-conjugated rabbit anti-goat IgG (Sigma) for $45 \mathrm{~min}$. After each incubation step, the cells were washed three times with PBS containing 0.2\% BSA. Fluorescence signals were analyzed via confocal microscopy.

Eight serial images of each immunostained sample were captured by Olympus FV1000 confocal laser scanning microscope with standard parameter settings. The immunofluorescence of control and C. pneumoniae infected cells was quantitatively analyzed by ImageQuant software (Molecular Dynamics) as follows: 6-6 equally sized circular areas covering the cells were randomly selected on each image. The backgrounds of the selected areas were eliminated by threshold set up and the fluorescence intensities/pixel values of the randomly selected cells were quantified. The mean and SD of the data gained from serial circular areas were calculated by means of Microsoft Excel. The level of statistical significance was determined by two-tailed t-test.

\subsection{Statistical ANALYSIS}

Statistical analyses for comparison of genotype frequencies between groups were performed by using the $\chi^{2}$ (chi-square) test, and Fisher's exact test if one cell had $n<5$. The probability level of $\mathrm{p}<0.05$ indicated statistical significance. The relationship between genotypes and disease severity is presented as the odds ratio (OR), with a $95 \%$ confidence interval $(95 \% \mathrm{CI})$. The genotype frequencies for each polymorphism were tested for deviation from the Hardy-Weinberg equilibrium by means of the $\chi^{2}$ test, with one degree of freedom used. Statistical calculations were performed with the Graph Pad Prism 5 (Graph Pad Software Inc., San Diego, CA) statistical program. Linkage disequilibrium estimation was performed using http:/www.chgb.org.cn/lda/lda.htm.

For the quantification of HBD-2 expression using RT-PCR and ELISA, all values are expressed as mean $\pm \mathrm{SD}$. results from $C$. pneumoniae infected samples were compared with non-infected controls. The data were subjected to two-tailed paired Student's test. For all statistical evaluations, $\mathrm{p}<0.05$ was considered statistically significant. Data analyses were performed by Graph PadPrism 5 (GraphPad Software Inc., San Diego, CA,USA) statistical program. 


\section{RESULTS}

\subsection{RAGE Gene Polymorphisms in Patients with Multiple Sclerosis}

\subsubsection{RAGE -374T/A Polymorphism}

The genotypic distribution of RAGE -374T/A polymorphism is shown in Table 1. The distribution of the genotypes was in accordance with the Hardy-Weinberg equilibrium both in the control group and in the MS patients ( $\mathrm{p}=0.975$ and 0.999 , respectively). There was a significant difference in genotypes between the patients and healthy controls $\left(\chi^{2}\right.$ test, $\mathrm{p}=0.003$ ). It was a lower frequency of the AA genotype among the patients with MS as compared with controls: 14 of the 168 patients (8\%) versus 25 of 131 healthy controls (19\%); $\mathrm{OR}=2.75$ vs. controls, $95 \% \mathrm{CI}=1.319-5.733, \mathrm{p}=0.007$. Conversely, a higher frequency of $\mathrm{TT}$ genotype was observed among MS patients $(84 / 168=50 \%)$ than among in controls (43 of $131=33 \%$; $\mathrm{OR}=2.22$ vs. controls, $95 \% \mathrm{CI}=1.322-3.747, \mathrm{p}=0.003)$. It is noteworthy that none of the 14 patients with SP type MS carried the AA genotype.

Table 1. RAGE -374T/A genotypes in patients with multiple sclerosis

\begin{tabular}{ccccc}
\hline $\mathbf{- 3 7 4}$ T/A & TT & TA & AA & \\
\hline MS patients & $84 / 168(50 \%)^{* *}$ & $70 / 168(42 \%)$ & $14 / 168(8 \%)^{*}$ & $\mathrm{p}=0.003^{\mathrm{a}}$ \\
Controls & $31 / 100(31 \%)$ & $49 / 100(49 \%)$ & $20 / 100(20 \%)$ & \\
\hline
\end{tabular}

${ }^{\mathrm{a}}$ Chi-square test vs. controls; ${ }^{*} \mathrm{p}=0.007$, Fisher test, $\mathrm{OR}=2.75$ vs. controls, 95\% CI: 1.319$5.733 ; * * p=0.003$, Fisher test, $\mathrm{OR}=2.22$ vs. controls, $95 \%$ CI: $1.322-3.747$

\subsubsection{RAGE -429T/C Polymorphism}

The distribution of the genotypes was in accordance with the Hardy-Weinberg equilibrium both in the control group and in the MS patients $(p=0.646$ and $p=0.323$, respectively).There was no significant difference in the $-429 \mathrm{~T} / \mathrm{C}$ genotypic distribution between the patients with MS and the healthy controls.

\subsubsection{RAGE G82S Polymorphism}

One hundred eight DNA samples from the control group and 103 samples from the MS patients were further available for investigation of the G82S SNP. The distribution of the genotypes was in accordance with the Hardy-Weinberg equilibrium both in the control population $(p=0.976)$ and in the patients with MS $(p=0.970)$. There was no significant difference in the G82S genotypic distribution between the patients with MS and the healthy controls We could not detect the SS homozygote genotype in either the controls or the MS group. The frequencies of the GG and GS genotypes were similar in the two groups. 
These results indicate, that that the $-374 T / A$ polymorphism of RAGE is a risk factor for MS in general and influences the development of the secondary relapsing form of the disease rather than simply the severity.

\subsection{NOD1 C.796G>A POLYMORPHISM AMONG CHLAMYDOPHILA PNEUMONIAE SEROPOSITIVE STROKE PATIENTS}

The distribution of the NOD1 genotypes was in accordance with the Hardy-Weinberg equilibrium both amongst the control population $\left(\chi^{2}=0.98, p=0.322\right)$ and amongst the patient group $\left(\chi^{2}=1.55, \mathrm{p}=0.213\right)$. Data relating to the genotypic distribution of the $\mathrm{c} .796 \mathrm{G}>\mathrm{A}$ polymorphism of the NOD1 gene are presented in Table 2. There was no significant difference in the genotype distribution between the patients overall and the healthy controls $\left(\chi^{2}=4.2, \mathrm{p}=0.121\right)$. When the Chlamydophila pneumoniae seropositivity was taken into account, a considerable difference in frequency of the NOD1 polymorphism was observed between the overall group of $C$. pneumoniae-positive patients and $C$. pneumoniae-positive controls $\left(\chi^{2}=21.813, \mathrm{p}<0.001\right)$. No significant difference was observed; however, between the NOD1 genotypes of controls and patients amongst the $C$. pneumoniae-negative groups. The AA homozygote and GA heterozygote mutant variants were detected in 16\% (25 of 152) and in 51\% (77 of 152) of the C. pneumoniae-positive stroke patients, as compared with $7 \%$ (6 of 84), and 29\% (24 of 84), respectively, in the C. pneumoniae-positive healthy controls. $(\mathrm{OR}=2.559 ; 95 \% \mathrm{CI}=1.105-6.517, \mathrm{p}=0.04$, and $\mathrm{OR}=2.56795 \% \mathrm{CI}=1.451-4.540 ; \mathrm{p}<0.001$, respectively). The frequency of A allele was $42 \%$ in C. pneumoniae-positive stroke patients, whereas it was only $21 \%$ in C. pneumoniae-positive controls. The difference in genotype amongst $C$. pneumoniae-positive subjects was more striking, when the patients were stratified into the small vessel and large vessel groups (Table 3.). Those in large vessel group displayed the highest frequency of the mutated allele A (51\%). The frequency of the GA genotype was $56 \%$ (37 of 66) amongst the Chlamydophila-positive stroke patients with large vessel disease, which means an OR of $3.19,95 \% \mathrm{CI}: 1.618-6.288, \mathrm{p}=0.0008$, as compared with the Chlamydophila-positive control subjects (24 of 84; 29\%). The difference in the frequency of AA homozygotes was even higher amongst these groups, with an OR of 3.824; $95 \%$ CI: 1.362-10.50, $\mathrm{p}=0.008$ (Table 2.). Conversely, the prevalence of the GG, wild type genotype was significantly lower in the group of patients with the large vessel pathology, than in the controls and those with small vessel disease; $21 \%$ (14 of 66) vs. 64\% (54 of 84) and 42\% (36 of 86), respectively. (OR=0.162, 95\% CI: $0.076-0.341, \mathrm{p}<0.001$; and $\mathrm{OR}=0.405,95 \% \mathrm{CI}$ : $0.194-0.843, p=0.021$, respectively.) In contrast, the difference in the genotype frequencies between the stroke patients with small vessel disease and the controls was less marked; considering the GA genotype, there was an OR of $2.177 ; 95 \%$ CI: $1.510-4.104, p=0.01$; and 
there was no significant difference in the frequency of the AA genotype, i.e., 11\% (10 of 86) vs. $8 \%(6 / 84), p=0.43$. Therefore, we conclude that the SNP of the NOD1 c.796G $>$ A gene is significantly higher amongst Chlamydophila-positive stroke patients, and the highest frequencies of the GA and $\mathrm{AA}$ genotypes are to be observed amongst those patients, with large vessel disease. In other words, Chlamydophila-positivity with polymorphism of the NOD1 c.796G $>A$ gene is a higher risk factor for the development of stroke with large vessel disease than with small vessel disease. Interestingly, amongst the $C$. pneumoniaenegative patients, no significant difference in genotype frequency was observed between the patients with large vessel disease and those with small vessel disease.

Table 2. NOD1 c.796G $>$ A genotypes in stroke patients

\begin{tabular}{|c|c|c|c|c|}
\hline & GG & GA & $\mathbf{A A}$ & A\% \\
\hline \multicolumn{5}{|l|}{ Stroke patients } \\
\hline Chlamydia $+* *$ & $50 / 152(33 \%)$ & $77 / 152(51 \%)^{b}$ & $25 / 152(16 \%)^{\mathrm{a}}$ & $42 \%$ \\
\hline Chlamydia - & $90 / 128(70 \%)$ & $30 / 128(23 \%)$ & $8 / 128(6 \%)$ & $18 \%$ \\
\hline Total* & $140 / 280(50 \%)$ & $107 / 280(38 \%)$ & $33 / 280(12 \%)$ & $31 \%$ \\
\hline \multicolumn{5}{|l|}{ Controls } \\
\hline Chlamydia + & $54 / 84(64 \%)$ & $24 / 84(29 \%)$ & $6 / 84(7 \%)$ & $21 \%$ \\
\hline Chlamydia - & $36 / 66(55 \%)$ & $24 / 66(36 \%)$ & $6 / 66(9 \%)$ & $27 \%$ \\
\hline \multicolumn{5}{|c|}{$\begin{array}{l}* \chi^{2}=4.2, p=0.121 \text { n.s. versus total controls; } * * \chi^{2}=21.813, p=<0.001 \text { versus Chlamydia-positive } \\
\text { controls; }{ }^{a} \text { Fischer test, OR=2.559 versus Chlamydia-positive controls; } 95 \% \text { CI: } 1.105-6.517 \text {, } \\
p=0.04 ;{ }^{b} \text { Fischer test, OR=2.567 versus Chlamydia-positive controls. } 95 \% \text { CI: } 1.145-4.540 \text {, } \\
\mathrm{p}<0.001 \text {. }\end{array}$} \\
\hline
\end{tabular}


Table 3. Distribution of the NOD1 c.796G $>$ A genotypes in stroke patients as regards the large vessel group and small vessel group

\begin{tabular}{ccccc}
\hline & GG & GA & AA & A\% \\
\hline $\begin{array}{c}\text { Stroke patients } \\
\text { Chlamydia }+\end{array}$ & $50 / 152(33)$ & $77 / 152(50)$ & $25 / 152(16)$ & 42 \\
\hline Large & $14 / 66(21)$ & $37 / 66(56) \mathrm{b}$ & $15 / 66(23) \mathrm{a}$ & 51 \\
Small & $36 / 86(42)$ & $40 / 86(46) \mathrm{d}$ & $10 / 86(11) \mathrm{c}$ & 34 \\
Chlamydia - & $90 / 128(70)$ & $30 / 128(24)$ & $8 / 128(6)$ & 17 \\
$\quad$ Large & $36 / 51(70)$ & $11 / 51(22)$ & $4 / 51(8)$ & 18 \\
Small & $54 / 77(70)$ & $19 / 77(25)$ & $4 / 77(5)$ & 17 \\
Total & $140 / 280(50)$ & $107 / 280(38)$ & $33 / 280(12)$ & 31 \\
Controls & & & & 21 \\
Chlamydia + & $54 / 84(64)$ & $24 / 84(28)$ & $6 / 84(8)$ & 27 \\
Chlamydia - & $36 / 66(54)$ & $24 / 66(37)$ & $6 / 66(9)$ & 24 \\
\hline Total & $90 / 150(60)$ & $48 / 150(32)$ & $12 / 150(8)$ & \\
\hline
\end{tabular}

\subsection{GENETIC POLYMORPHISMS OF BETA-DEFENSINS IN SEVERE ACUTE PANCREATITIS}

\subsubsection{DEFB1 c.-20G $>$ A polymorphism}

The distribution of the DEFB1 c.-20G>A genotypes was in accordance with the Hardy-Weinberg equilibrium in the control population $\left(p=0.996, \chi^{2}=0.001\right)$ and also in the patient group $\left(\mathrm{p}=0.665, \chi^{2}=0.199\right)$. The genotypic distribution of the $\mathrm{c} .-20 \mathrm{G}>\mathrm{A}$ polymorphism of the DEFB1 gene is shown in Table 4. There was a significant difference in genotype distribution between the pancreatitis patients overall and healthy controls $(p=0.03)$. When the patients were stratified according the disease severity, a more significant difference was observed only between the controls and the patients with severe pancreatitis $(p=0.009)$, but not between the controls and patients with mild pancreatitis $(p=0.44)$, when the genotypes were taken into consideration. Thereafter we compared the numbers of AA homozygotes among the patients with severe pancreatitis and the controls. As shown in Table 4., there was a higher frequency (38\%) of the AA genotype among the patients with severe disease as compared with the controls $(20 \%)$; OR $=2.48,95 \%$ CI: $1.305-4.722, p=0.006$. The highest frequency of AA genotype was observed among patients with infected pancreatic necrosis (61\%). The carriage of the A allele was also significantly different between the patients with SAP (63\%) and the healthy blood donor group (44\%). Conversely, the prevalence of the 
DEFB1 c.-20 GG wild type genotype was significantly lower (11\%) in the group of patients with severe acute pancreatitis than in the healthy control group (31\%).

Table 4. DEFB1 c. $-20 \mathrm{G}>$ A genotypes in AP patients and controls

\begin{tabular}{cccccc}
\hline c.-20G $>\mathbf{A}$ & $\mathbf{G G}$ & $\mathbf{G A}$ & $\mathbf{A A}$ & $\chi^{2}$ test vs. control & $\mathbf{A} \%$ \\
\hline AP patients & $21 / 124(17 \%)$ & $66 / 124(53 \%)^{\mathrm{a}}$ & $37 / 124(30 \%)^{\mathrm{e}}$ & $\mathrm{p}=0.03$ & 56 \\
Severe AP & $10 / 94(11 \%)$ & $48 / 94(51 \%)^{\mathrm{b}}$ & $36 / 94(38 \%)^{\mathrm{g}}$ & $\mathrm{p}=0.009$ & 63 \\
$\quad$ Infected & $4 / 29(14 \%)$ & $10 / 29(34 \%)^{\mathrm{c}}$ & $15 / 29(61 \%)^{\mathrm{h}}$ & $\mathrm{p}=0.002$ & 69 \\
Mild AP & $10 / 30(33 \%)$ & $17 / 30(57 \%)^{\mathrm{d}}$ & $3 / 30(10 \%)^{\mathrm{f}}$ & $\mathrm{p}=0.44$ & 38 \\
Controls & $31 / 100(31 \%)$ & $49 / 100(49 \%)$ & $20 / 100(20 \%)$ & & 44 \\
\hline
\end{tabular}

Fisher's test vs. control: ${ }^{\mathrm{a}} \mathrm{p}=0.591, \mathrm{OR}=1.184,95 \%$ CI: $0.698-2.007 ;{ }^{\mathrm{b}} \mathrm{p}=0.885, \mathrm{OR}=1.086$, 95\% CI: $0.618-1.908 ;{ }^{c} \mathrm{p}=0.206, \mathrm{OR}=0.547,95 \%$ CI: $0.231-1.295 ;{ }^{\mathrm{d}} \mathrm{p}=0.534, \mathrm{OR}=1.361,95 \%$ CI: $0.598-3.096 ;{ }^{e}=0.122$, OR $=1.701,95 \%$ CI: $0.912-3.172 ;{ }^{f}=0.28$, OR $=0.444,95 \%$ CI: $0.122-1.614 ;{ }^{\mathrm{g}} \mathrm{p}=0.006, \mathrm{OR}=2.48,95 \% \mathrm{CI}: 1.305-4.722 ;{ }^{\mathrm{h}} \mathrm{p}=0.001, \mathrm{OR}=4.286,95 \%$ CI: $1.781-$ 10.31 .

\subsubsection{DEFB1 c.-44C $>$ G polymorphism}

The distribution of DEFB1 c. $-44 C>G$ genotypes was in accordance with the HardyWeinberg equilibrium among the patients with acute pancreatitis $\left(p=0.610, \chi^{2}=0.260\right)$ and also in the control population $\left(p=0.597, \chi^{2}=0.279\right)$. The genotypic distribution of the DEFB1 c. $-44 \mathrm{C}>\mathrm{G}$ polymorphism is shown in Table 5. There was a significant difference in genotype distribution between the patients overall and the healthy controls $\left(\chi^{2}\right.$ test, $\left.p=0.02\right)$. When the patients were stratified according the disease severity, a significant difference was observed only between the controls and patients with severe pancreatitis $(p=0.03)$ and not between the controls and patients with mild pancreatitis, $(p=0.84)$. Interestingly, there was a lower frequency of the GG genotype among the patients with pancreatitis as compared with the controls: 2 of the 124 patients with acute pancreatitis (1\%) and none of patients with severe acute pancreatitis $(0 \%)$ vs. 9 of the 100 healthy controls (9\%). Conversely, the prevalence of the DEFB1 c.-44CC genotype was $72 \%$ in the group of patients with severe acute pancreatitis vs. $56 \%$ of controls; Fisher test: $\mathrm{p}=0.02, \mathrm{OR}=2.055,95 \%$ CI: $1.27-3.745$. 
Table 5. DEFB1 c.-44C $>$ G genotypes in AP patients and controls

\begin{tabular}{lccccc}
\hline & CC & CG & GG & $\chi^{2}$ test vs. control & G\% \\
\hline AP patients & $84 / 124(68 \%)^{\mathrm{e}}$ & $38 / 124(31 \%)^{\mathrm{a}}$ & $2 / 124(1 \%)$ & $\mathrm{p}=0.02$ & 17 \\
Severe AP & $68 / 94(72 \%)^{\mathrm{g}}$ & $26 / 94(28 \%)^{\mathrm{b}}$ & $0 / 94(0 \%)$ & $\mathrm{p}=0.003$ & 14 \\
\multicolumn{1}{c}{ Infected } & $24 / 29(82 \%)^{\mathrm{h}}$ & $5 / 29(7 \%)^{\mathrm{c}}$ & $0 / 29(0 \%)$ & $\mathrm{p}=0.02$ & 9 \\
Mild & $16 / 30(53 \%)^{\mathrm{f}}$ & $12 / 30(40 \%)^{\mathrm{d}}$ & $2 / 30(7 \%)$ & $\mathrm{p}=0.84$ & 26 \\
Controls & $56 / 100(56 \%)$ & $35 / 100(35 \%)$ & $9 / 100(9 \%)$ & & 26 \\
\hline Fisher's test vs. control: ${ }^{\mathrm{a}} \mathrm{p}=0.565, \mathrm{OR}=0.820,95 \% \mathrm{CI}: 0.468-1.438 ;{ }^{\mathrm{b}} \mathrm{p}=0.283, \mathrm{OR}=0.701,95 \%$ \\
CI: $0.385-1.308 ;{ }^{\mathrm{p}}=0.07, \mathrm{OR}=0.386,95 \% \mathrm{CI}: 1.357-1.103 ;{ }^{\mathrm{d}} \mathrm{p}=0.667, \mathrm{OR}=1.238,95 \% \mathrm{CI}:$ \\
$0.535-2.863 ;{ }^{\mathrm{p}}=0.09, \mathrm{OR}=1.650,95 \% \mathrm{CI}: 0.956-2.845 ;{ }^{\mathrm{p}}=0.836, \mathrm{OR}=0.898,95 \% \mathrm{CI}: 0.395-$ \\
$2.037 ;{ }^{\mathrm{g}} \mathrm{p}=0.02, \mathrm{OR}=2.055,95 \% \mathrm{CI}: 1.27-3.745 ;{ }^{\mathrm{h}} \mathrm{p}=0.009, \mathrm{OR}=3.77,95 \% \mathrm{CI}: 1.331-10.69$. \\
\hline
\end{tabular}

\subsubsection{DEFB1 c.-52G $>$ A polymorphism}

The distribution of the DEFB1 c.-52G>A genotypes was in accordance with the Hardy-Weinberg equilibrium in the control population $\left(p=0.502, \chi^{2}=0.250\right)$ and also in the patient group $\left(p=0.997, \chi^{2}=0.0001\right)$. There was a significant difference in genotype distribution between the pancreatitis patients overall and healthy controls $(p=0.004)$. When the patients were stratified according the disease severity, a more significant difference was observed between the controls and patients with severe pancreatitis. $(p=0.001)$ and not between the controls and patients with mild pancreatitis, $(p=0.606)$ when the genotypes were taken into consideration (Table 6.) There was a higher frequency (41\%) of the AA genotype among the patients with severe disease as compared with the controls $(18 \%)$; OR $=3.23,95 \%$ CI: $1.678-6.218, p=0.0005$. The carriage of the A allele was also significantly different between the patients with severe pancreatitis (64\%) and the healthy blood donor group $(39 \%$,). Conversely, the prevalence of the DEFB1 c.-52GG wild type genotype was significantly lower (14\%) in the group of patients with severe acute pancreatitis than in the healthy control group (40\%). 
Table 6. DEFB1 c. $-52 \mathrm{G}>$ A genotypes in AP patients and controls

\begin{tabular}{lccccc}
\hline & GG & GA & AA & $\chi^{2}$ test vs. control & A, \% \\
\hline AP patients & $22 / 124(18 \%)$ & $60 / 124(48 \%)^{\mathrm{a}}$ & $42 / 124(34 \%)^{\mathrm{e}}$ & $\mathrm{p}=0.004$ & 58 \\
Severe & $13 / 94(14 \%)$ & $42 / 94(45 \%)^{\mathrm{b}}$ & $39 / 94(41 \%)^{\mathrm{g}}$ & $\mathrm{p}=0.001$ & 64 \\
\multicolumn{1}{c}{ Infected } & $2 / 29(7 \%)$ & $15 / 29(52 \%)^{\mathrm{c}}$ & $12 / 29(41 \%)^{\mathrm{h}}$ & $\mathrm{p}=0.001$ & 67 \\
Mild & $9 / 30(30 \%)$ & $18 / 30(60 \%)^{\mathrm{d}}$ & $3 / 30(10 \%)^{\mathrm{f}}$ & $\mathrm{p}=0.606$ & 40 \\
Controls & $40 / 100(40 \%)$ & $42 / 100(42 \%)$ & $18 / 100(18 \%)$ & & 39 \\
\hline Fisher's test vs. control: ${ }^{\mathrm{a}} \mathrm{p}=0.348, \mathrm{OR}=1.295,95 \% \mathrm{CI}: 0.761-2.202 ;{ }^{\mathrm{b}} \mathrm{p}=0.772, \mathrm{OR}=1.115,95 \%$ \\
CI: $0.631-1.969 ;{ }^{\mathrm{p}}=0.399, \mathrm{OR}=1.480,95 \% \mathrm{CI}: 0.713-2.567 ;{ }^{\mathrm{d}} \mathrm{p}=0.093, \mathrm{OR}=2.071,95 \% \mathrm{CI}:$ \\
$0.911-4.758 ;{ }^{\mathrm{e}} \mathrm{p}=0.009, \mathrm{OR}=2.333,95 \% \mathrm{CI}:$ & $1.241-4.388 ;{ }^{\mathrm{f}} \mathrm{p}=0.401, \mathrm{OR}=0.506,95 \% \mathrm{CI}:$ \\
$0.138-1.853 ;{ }^{\mathrm{g}} \mathrm{p}=0.0005, \mathrm{OR}=3.230,95 \% \mathrm{CI}:$ & $1.678-6.2185 ;{ }^{\mathrm{h}} \mathrm{p}=0.012, \mathrm{OR}=3.216,95 \% \mathrm{CI}:$ \\
$1.310-7.895$. &
\end{tabular}

\subsubsection{Copy number polymorphism of human beta-defensin-2}

In the control group the copy numbers had a range of 2-10 per genome, with a median number of 4 copies. The proportions of control individuals who carry the median (4), less than median $(<4)$ or more than median $(>4)$ number of copies were $24 \%, 40 \%$ and $36 \%$ respectively. In patients with acute pancreatitis the frequency distribution of the subgroups was significantly different from that of the control group ( $p=0.001$, Figure 4.). $42 \%$ of patients with acute pancreatitis overall had a lower copy number $<4$, while in patients with severe acute pancreatitis the frequency of a low copy number $(<4)$ was $62 \%$, and that of a copy number $>4$ was only $10 \%$ (Figure 4.).

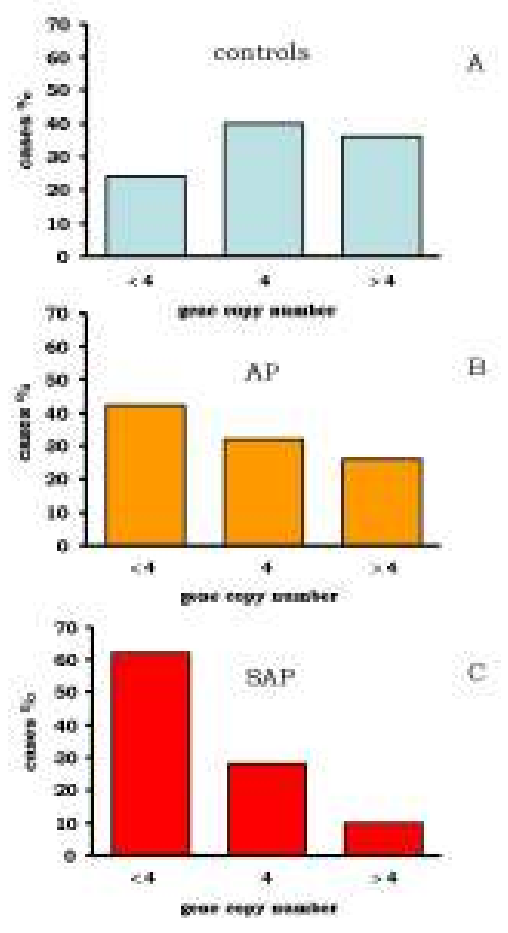

Figure 4. Distribution of HBD-2 gene (DEFB4) copy numbers in the controls (grey bars) and in the patients with mild AP (orange bars) and SAP (red bars) allocated to $<4,4$ or $>4$ copies per genome. ${ }^{*} \mathrm{p}=0.02$ for the controls vs. the AP group, and $* * p=0.001$ for the controls vs. the SAP group $\left(\chi^{2}\right.$ test $)$

These results indicate the relevance of genetic variations in the genes encoding human $\beta$-defensin-1 and 2 in the development of severe acute pancreatitis. 


\subsection{INDUCIBLE EXPRESSION OF HUMAN B-DEFENSIN 2 BY CHLAMYDOPHILA PNEUMONIAE IN BRAIN CAPILLARY ENDOTHELIAL CELLS}

\subsubsection{Expression of human B-defensin 2 mRNA in BB19 cells and increase in expression by $C$. pneumoniae}

To determine whether HBD-2 gene expression is induced in BB19 cells in response to C. pneumoniae infection, RT PCR was performed. A time-dependent increase in HBD- 2 mRNA was observed in BB19 cells (Figure 5.). The maximum increase in HBD-2 mRNA expression was observed at $24 \mathrm{~h}$ at a MOI of 5 IFU. The infection of endothelial cells by CV6, a cardiogenic strain, resulted in a more pronounced expression of HBD-2 mRNA. We compared the effects of heat-inactivated $C$. pneumoniae with those of viable $C$. pneumoniae. In cells stimulated with heat-inactivated $C$. pneumoniae, the expression of HBD-2 was induced, although at a reduced level (Figure 5.). Mock preparations did not result in any increase in HBD-2 mRNA level (data not shown).

We tested also the constitutive HBD-1 expression in BB19 cells. In contrast to HBD2, there was no any increase in expression of HBD-1 mRNA following C. pneumoniae infection (data not shown).

Figure 5. Time-dependent increase in human $\beta$-defensin-2 (HBD-2) mRNA expression by $C$.

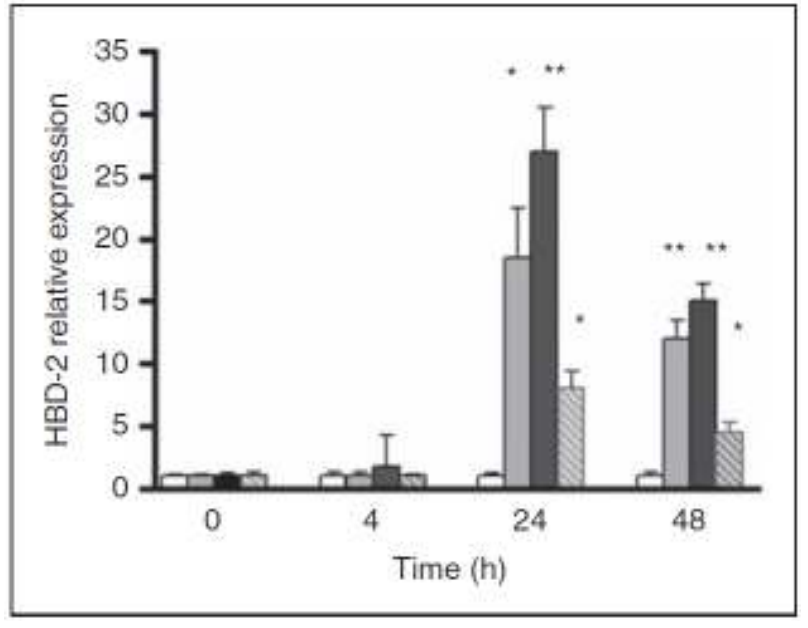
pneumoniae. BB19 cells were infected with C. pneumoniae CWL 029 (grey bars) and with acardiovascular strain of $C$. pneumoniae CV6 (black bars) or with heatinactivated C. pneumoniae CV6 (hatched bars) at a multiplicity of infection of 5 IFU for the time indicated. Open bars: BB19 cells alone (control cells). HBD-2 levels were normalized to GAPDH by using quantitative real-time PCR. Results are expressed as mean $\pm \mathrm{SD}$ of the data from three experiments. Asterisks indicate a statistically significant difference between the data from the experimental test and the control test: ${ }^{*} \mathrm{p}<0.01,{ }^{* *} \mathrm{p}<0.001$.

\subsubsection{Human B-defensin 2 protein expression in BB19 cells infected with $C$. pneumoniae} The expression of HBD-2 protein in C. pneumoniae infected endothelial cells was determined by immunoblotting. Through use of the anti-HBD-2 antibody which binds to human betadefensin 2 , a single band of about $4 \mathrm{kDa}$ was detected. The signal was strong following the blotting of cell lysates from $C$. pneumoniae-infected cells. The level of HBD-2 was only 
barely detectable after the processing of the control cell lysate without C. pneumoniae infection (Figure 6.).

Figure 6. Immunoblotting analysis of HBD-2 peptide expression in C. pneumoniae-infected

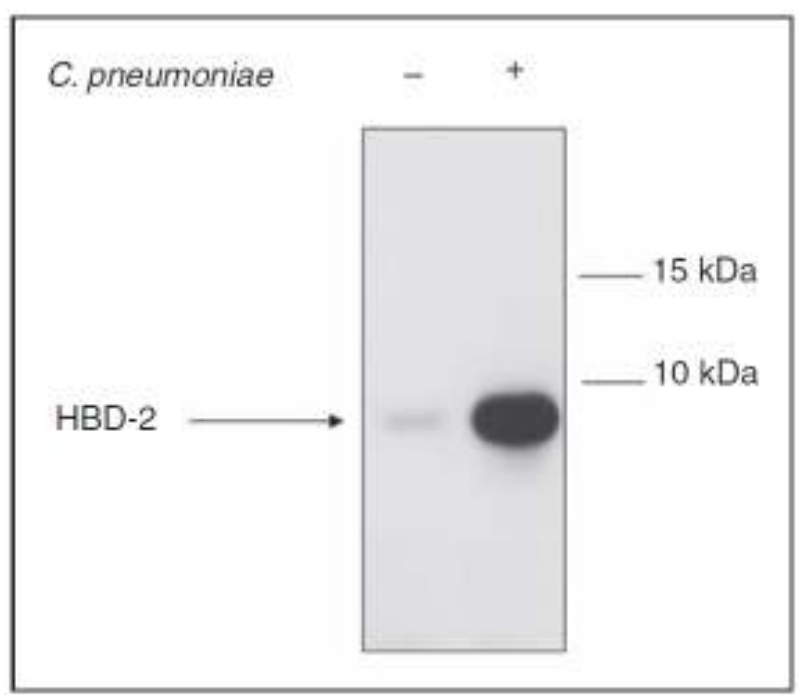
brain capillary endothelial cells. BB19 cell cultures were infected with $C$. pneumoniae at a MOI of 5 IFU for $24 \mathrm{~h}$. Total cellular protein $(25 \mathrm{mg})$ from each culture was loaded on a $15 \%$ SDS-PAGE gel for immunblotting. After transfer, the membranes were incubated with anti-human goat HBD-2 antibody. Human ß-defensin 2 was detected with ECL. Lane 1 relates to a culture without infection, Lane 2 to a culture with C. pneumoniae infection for $24 \mathrm{~h}$. These results are representative of three experiments performed independently. 


\subsubsection{Immunofluorescent staining of BB19 cells for HBD-2}

Immunofluorescent staining images of $C$. pneumoniae infected BB19 cells revealed that HBD-2 was diffusely distributed as granules throughout the cytoplasm of the endothelial cells (Figure 7.). There was only a weak fluorescence in the uninfected controls. The calculated fluorescence intensity mirrored the ELISA (Figure 7.) and Western blotting results, indicating that the HBD-2 protein was highly inducible.

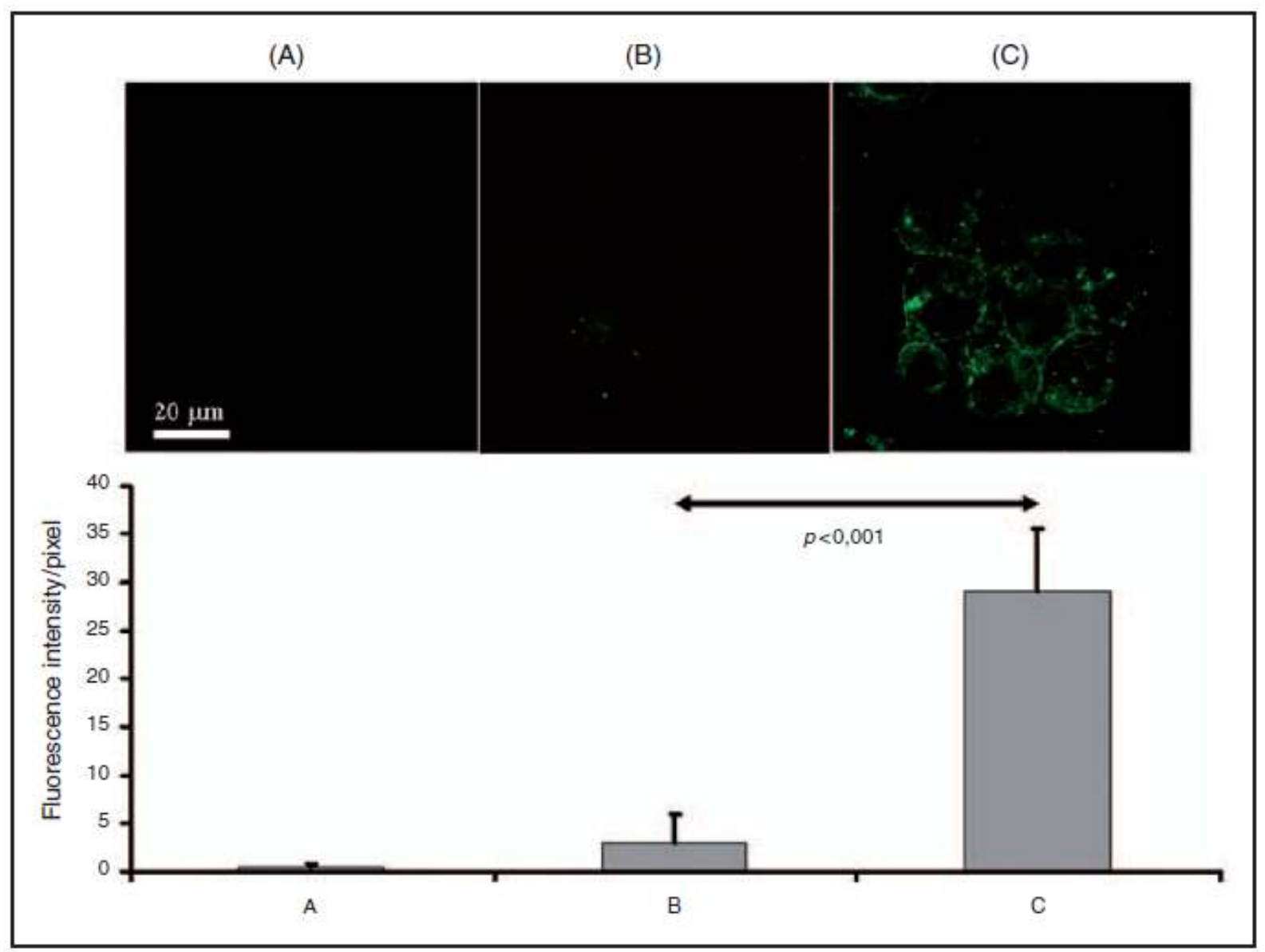

Figure 7. Immunofluorescence analysis of the HBD-2 peptide in BB19 cells. Cells were uninfected or infected with C. pneumoniae for $24 \mathrm{~h}$. They were then harvested, and Cytospin preparations were stained for HBD-2 with goat anti-human HBD-2 antibody, and thereafter with secondary antibody (FITC labeled anti-goat antibody). Serial fluorescence images were captured by confocal microscopy and analyzed statistically. (A) Isotype control; (B) control cells without infection; and (C) cells infected with C. pneumoniae for $24 \mathrm{~h}$.

\subsubsection{Chlamydophila pneumoniae induces HBD-2 secretion by BB19 cells}

Experiments were performed to determine the HBD-2 protein secreted by BB19 cells into the tissue culture medium following $C$. pneumoniae infection. The amount of HBD-2 in the supernatants was determined by ELISA. Results of these experiments showed that the concentration of HBD-2 protein was significantly elevated in the supernatant $24 \mathrm{~h}$ after $C$. 
pneumoniae infection (Figure 8.). The supernatants from BB19 cells stimulated with heatinactivated $C$. pneumoniae displayed a moderate release of HBD-2 peptide (Figure 8.).

The BB19 cells incubated with mock stocks exhibited a similar level of HBD-2 release as that of the noninfected controls (data not shown). In parallel experiments, the concentration of HBD-2 was also determined in the cell lysates. A considerable increasing the amount of HBD-2 was detected in the cell lysates of cultures infected with C. pneumoniae CWL-029 or with C. pneumoniae CV6 for $24 \mathrm{~h}(35.2 \pm 3.8 \mathrm{pg} / \mathrm{ml}$ and $48.4 \pm 4.6 \mathrm{pg} / \mathrm{ml}$, respectively, vs 5.5 $\pm 2.8 \mathrm{pg} / \mathrm{ml}$ in the control cell lysates).

These results imply that human endothelial cells stimulated by $C$. pneumoniae induce the expression of the HBD-2 gene and the release of HBD-2 protein into the medium.

Figure 8. Kinetics of HBD-2 peptide production in culture supernatants from C. pneumoniae

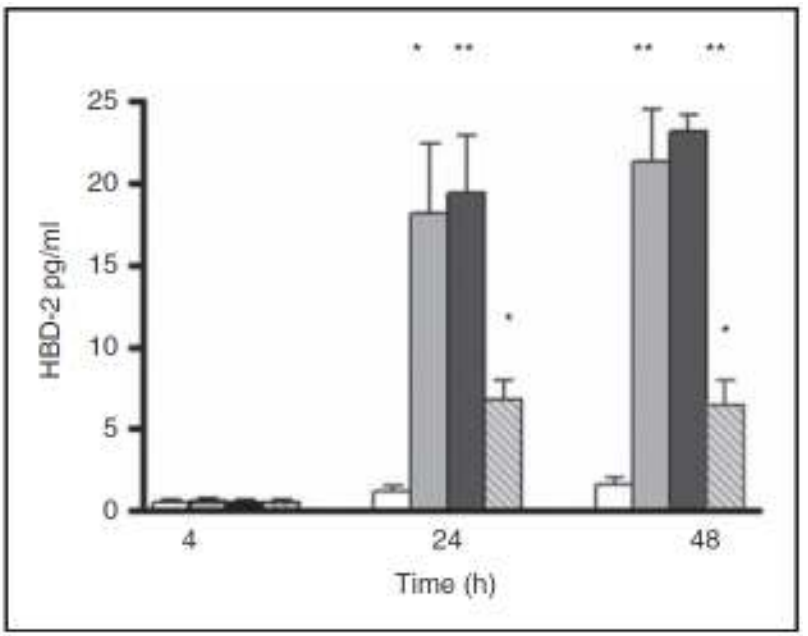
infected BB19 cells. BB19 cells were infected with C. pneumoniae CWL-029 (grey bars) or with C. pneumoniae CV6 (black bars) or with heat-inactivated $C$. pneumoniae CV6 (hatched bars) at a multiplicity of infection of 5 IFU for the indicated periods and culture supernatants were harvested. Open bars: BB19 cells uninfected (control). The levels of HBD-2 were measured by ELISA. Values are mean + SD of the data from three independent experiments. Asterisks indicate a statistically significant difference between the data from the experimental test and the control test: ${ }^{*} \mathrm{p}<0.01,{ }^{* *} \mathrm{p}<0.001$.

Our results indicate, that $\mathrm{HBD}-2$ is expressed and produced in the human brain capillary endothelial cells upon infection with Chlamydophila pneumoniae, and provide evidence that HBD-2 plays a role in the early immune responses to $C$. pneumoniae and probably in the immunopathogenesis of atherosclerosis. 


\section{DISCUSSION}

\subsection{RAGE Gene Polymorphisms in Patients With Multiple Sclerosis}

The up-regulation and pathogenic effects of RAGE in MS highlight the RAGE gene as a candidate for involvement in the pathogenesis of the disease.

Our results have demonstrated an association between the $-374 \mathrm{~T} / \mathrm{A}$ polymorphism of the RAGE promoter and MS; the frequency of the AA genotype was significantly higher in the control group than in MS patients, suggesting that the AA genotype may have a protective role against the development of MS. Recent studies have suggested a protective role of AA genotype of the -374T/A SNP toward the development of coronary atherosclerosis [98]. There was no significant difference in genotype between men and women nor in genotype distribution if the patients were stratified overall according to the severity of the disease. However, it is noteworthy that none of the patients with the SP type of MS exhibited the AA genotype, though the number of these patients in our study was low (14). Therefore, we presume that the $-374 \mathrm{~T} / \mathrm{A}$ polymorphism of RAGE is a risk factor for MS in general and influences the development of the secondary relapsing form of the disease rather than simply the severity.

The $-374 \mathrm{~T} / \mathrm{A}$ polymorphism of RAGE gene located in the promoter region of the gene has previously been shown to exert significant effects on transcriptional activity [22]. Our results raise the question of how the altered transcription of the RAGE promoter region can affect the risk of MS. We presume that altered transcription may lead to a reduced degree of expression of the RAGE, which could limit the activation of multiple RAGE-mediated signaling pathways, leading to a different level of susceptibility to MS. There was no difference in frequency of $-479 \mathrm{~T} / \mathrm{C}$ genotype between the MS patients and the controls. In accordance with this result, the study of Hudson et al. (2001) did not reveal any clear differences in actual protein-DNA interactions in the case of the $-429 \mathrm{~T} / \mathrm{C}$ polymorphism, but a very distinct difference in transcription factor binding was observed between the $-374 \mathrm{~T}$ and A alleles. The $\mathrm{T}$ to A substitution appeared to prevent the binding of nuclear factor, which suggested that a disruption of nuclear protein is involved in repression of RAGE transcription. Transcription factor binding assays revealed the abolition of a nuclear protein binding site with the introduction of the -374 A allele, supporting the role rather of this polymorphisms and not of $-429 \mathrm{~T} / \mathrm{C}$ in affecting RAGE transcription repression.

As concerns the Gly82 $\rightarrow$ Ser polymorphism, Ser82 enhances receptor signaling through mitogen activated protein kinases and nuclear factor of kappa B [23]. However, the 
RAGE Gly82 $\rightarrow$ Ser polymorphism showed no association with MS in our study. Hence, we assume that inhibition of the expression of RAGE itself and not the modulation of signaling may be a definitive factor in MS. In conclusion, we suppose that the altered transcription induced by the $-374 \mathrm{~T} / \mathrm{A}$ SNP could lead to a reduced level of RAGE, which might be a factor protecting against the development of MS. Our findings support the view that RAGE plays a role in the development of MS. Further studies will elucidate whether blockade of RAGE has a therapeutic potential for the prevention of brain tissue injury and neurodegeneration in MS.

\subsection{RELEVANCE OF THE GENETIC POLYMORPHISM OF NOD1 IN CHLAMYDOPHILA PNEUMONIAE SEROPOSITIVE STROKE PATIENTS}

The causation of ischemic stroke is multifactorial a combination of genetic risk factors and environmental factors [99]. Inflammatory parameters and chronic and acute infectious diseases have been considered to modify stroke risk independently of conventional risk factors. Sero-epidemiological studies are limited by the high prevalence of antibodies in adults. The risk due to a prior infection may be influenced by individual inflammatory response of the host. The relevance of single nucleotide polymorphisms of IL-6 and intercellular adhesion molecule 1 genes were reported in ischemic stroke [100, 101]. Toll-like receptors and NOD proteins are pattern recognition receptors, which are key elements in the regulation of immune response [102]. TLR4 is the transmembrane lipopolysaccharide receptor, which initiates the innate immune response to Gram-negative bacteria, including Chlamydophila pneumoniae. Kiechl et al. [103] reported that the Asp288Gly polymorphism of TLR4 predicted an inverse and reduced risk of atherosclerosis.

To check the importance of the difference in NOD1 genotype, we investigated the NOD1 SNP in stroke patients. Several SNPs in NOD1 has been described $[104,105]$. The G796A SNP was chosen in the coding sequence of the gene in exon 3, as it was earlier reported to encode a changed protein, (E266K) in the nucleotide binding domain altering a glutamic acid residue, suggesting a potential functional effect of the mutation [29].

It was recently found, that the NOD1 A allele is associated with reduced expression of NOD1 protein, leading to diminished NF-kB activation in response to Propionibacterium acnes [106]. It is suggested that the E266K substitution reduces the stability of NOD1. In addition to the induction of cytokines, NOD activation may be involved in signaling cascademediated defenzin expression [5, 24]. Any failure in the production of this natural antibacterial protein could lead to an imbalance between invading bacteria and the host innate immunity [3]. Thus, an impaired defensin synthesis might be linked to a higher rate of multiplication of invading bacteria. 
In our study, the NOD1 genetic polymorphism appeared to be a potential risk factor in ischemic stroke only in C. pneumoniae-infected patients. In other words, it may be speculated, that in the case of $C$. pneumoniae infection, a functional deficiency of the NOD1 signalling system could lead to a higher rate of multiplication of Chlamydophila and to a more intensive local inflammatory response.

Conversely, C. pneumoniae infection alone, with an appropriate immune response is not enough for a definitive inflammatory induction, and plaque formation in the blood vessels. This seems to be supported by the fact, that the proportion of Chlamydophila positivity was not significantly higher in our stroke patients. The results of the serological examinations are in contrast with the observation underlining the association with $C$. pneumoniae seropositivity in stroke [62, 63, 64]. In this sense, our results are in agreement with the finding of no association of $C$. pneumoniae antibodies with ischemic stroke $[68,69$, 70]. However, we did detect a significant association between the SNP of NOD1 receptor (which also detects C. pneumoniae) and stroke only in C. pneumoniae-positive patients.

To the best of our knowledge, this is the first report concerning the relevance of NOD1 polymorphism in the risk of ischemic stroke amongst Chlamydophila-positive patients. There were significant differences in NOD1 G796A genotype distribution between the controls and the stroke patients with $C$. pneumoniae infection. In the interpretation of our data, some limitations should be considered. The small number of subjects in our preliminary study is an indication of a need for caution. For a stronger power, the number of patients in each group should be increased appreciably, which requires a multicenter approach.

There is certainly no specific link between any chronic infectious disease and stroke, but it appears much more probably that the chronic infections are risk factors that act in cooperation with conventional risk factors and genetic predisposition, which are neither necessary nor sufficient for disease generation alone [58].

Polymorphism in NOD1 E266K is not a risk factor for stroke in general, but in association with C. pneumoniae infection it appeared to be accompanied by an increased risk of the development of stroke; therefore, it could prove to be a valuable marker for an assessment of the risk of stroke in combination with C. pneumoniae infection.

\subsection{RELEVANCE OF GENETIC POLYMORPHISMS OF BETA-DEFENSINS IN SEVERE ACUTE PANCREATITIS}

Maintenance of the integrity of the gut barrier is one of the goals in the treatment of severe acute pancreatitis. For this reason, enteral nutrition has been proposed for restoration and prevention of the morphological changes in the gut associated with fasting. More 
recently, another method involving the use of probiotics has been proposed to reduce the infection of necrosis by intestinal bacteria $[107,108]$. Apart from a direct or indirect action on other bacteria, it is believed, that probiotics act directly on the mucosal immune system, stimulating an increased production of $\beta$-defensins $[109,110]$.

On the basis of these observations, we presumed, that an investigation of the relevance of genetic polymorphisms of beta defensins in acute pancreatitis was plausible. We supposed that any decrease in defensin expression either in the colonic mucosa or locally in the pancreatic tissue could result a higher rate of bacterial translocation from the gut, or even an increased possibility of retrograde infection. The expression of HBD-1 mRNA in the pancreas acinar cells suggest that HBD-1 fulfills physiological functions in the host defense $[36]$.

Our analysis of DEFB1 c.-20G $>$ A genotypes among patients with AP revealed that the AA genotype comprises a higher risk of severe form of disease $(\mathrm{OR}=2.48)$. The functional significance of this SNP resides in the formation of a nuclear factor-kappa B transcription factor-binding sequence, and it likely that this mutation might cause a lower hBD1 expression in colonic epithelial cells [41] or in pancreatic acinar cells. Similarly, the G/A SNP at the -52 region of DEFB1 correlates with decreased expression of HBD-1 and this is in accordance with our results demonstrating a higher frequency of the A allele in patients with SAP. It is tempting to speculate that this mutation in the -52 untranslated region might cause a lower HBD-1 expression in epithelial cells with a deficient function of human defensin.

It is noteworthy, that 29 of the 94 patients in the SAP group suffered from infected necrosis with multiple organ failure, and 25 of them carried the A allele of c.-20G $>A$. Similarly, concerning the c.-52G $>$ A SNP, 27 of the 29 patients carried the mutant A allele. We therefore presume that individuals displaying the presence of the polymorphism may be predisposed to the most severe complications of acute necrotizing pancreatitis.

The present study has demonstrated that the distributions of c. $-44 \mathrm{C}>\mathrm{G}$ (according to the initiation codon-based nomenclature), also known as DEFB1 668C/G genotype, were different in the patients with SAP and the healthy controls, while the frequency of the GG genotype was significantly higher in the controls. This result indicates that the $\mathrm{C} / \mathrm{G}$ mutation probably leads to strengthened HBD1 antimicrobial activity, which is less frequent among patients with SAP. The c.-44C $>$ G SNP generates a putative binding site for nuclear factor-kB, and induces overexpression [41]. The proposed effect of this SNP could partially explain, why the GG genotype was considered to be a protective genotype in atopic dermatitis [111] and also in susceptibility to Candida colonization [112] and the risk of HIV infection [113]. 
In these studies, subjects carrying the CC genotype at the -44 locus site of the gene were at a greater risk of acquiring infection. In our previous studies a significant correlation was also observed between the DEFB1 SNPs and the colonic localization of Crohn's disease [46].

These data are consistent with our present observation that the GG phenotype could also be protective in acute pancreatitis. Again, among the 29 patients with infected necrotic pancreatitis only 5 carried the G allele, or protective allele, and none of them was GG homozygote. These observations draw attention to the importance of DEFB1 polymorphism especially as concerns a predisposition to infected pancreatic necrosis.

In the present study, acute pancreatitis was characterized by a shift to lower copy numbers of DEFB4 encoding HBD-2. A low beta-defensin gene copy number in Crohn's disease predisposing to colonic localization has been reported, most likely through diminished beta-defensin expression [114]. Similarly, we suppose, that in our study individuals with $<4$ copies are at a higher risk of developing severe acute pancreatitis because of an impaired HBD-2 expression rate.

To the best of our knowledge, this is the first time that three DEFB1 SNPs have been tested for a possible association with acute pancreatitis. The DEFB1 G-20A and DEFB1 C44G and DEFB1 G-52A SNPs differed between the patients with SAP and the healthy controls. Additionally, the low copy number of DEFB4 - the gene of human defensin $\beta-2$ - in patients with SAP draws attention to the importance of defensins in development of severe form of AP.

Our results should be regarded as preliminary results, indicating the relevance of the SNPs in the genes encoding HBD-1 and HBD-2 in acute pancreatitis and especially in infected SAP, which should be confirmed on a larger series of patients in a future multicentre study.

Although the SNP may be only one of the factors that contribute to the susceptibility to SAP, our data further support the idea, that SAP could be due also to the defective production of beta-defensins.

It is unlikely that a single modifier gene alone is responsible for SAP. It is more likely, that the combination of a multitude of SNPs, in different genetic loci and genes, contribute to produce the clinical phenotype of SAP. The identification of the variants of the DEFB1 and DEFB4 genes may contribute to a better understanding of the pathogenesis of this disease. 


\subsection{INDUCIBLE EXPRESSION OF HUMAN B-DEFENSIN 2 BY CHLAMYDOPHILA PNEUMONIAE IN BRAIN CAPILLARY ENDOTHELIAL CELLS}

Expression of defensins in human endothelial cells in response to Chlamydophila pneumoniae has not been studied previously. Sero-epidemiological studies in patients with stroke have provided evidence of an association of risk with prior infection with $C$. pneumoniae [63, 66]. The endothelial dysfunction observed in stroke patients has been related to the physiopathology of stroke, the stroke subtypes, the clinical severity and the outcome [89]. The present study was performed to analyze the expression of HBD-2 and the effects of C. pneumoniae on HBD-2 expression in the human brain capillary endothelial cell line BB19.

Human $\beta$-defensin 2, an antimicrobial peptide, has so far been found exclusively in a variety of epithelial cells. No data are available on HBD-2 expression in endothelial cells except for the very recent publication by Kawsar et al. [119], which reported the expression of HBD-2 in the intratumoral vascular endothelium and HUVECs (human umbilical vein endothelial cells).

In our study, the expression of HBD-2 mRNA in brain capillary endothelial cells was first assessed by RT-PCR. As mRNA may not always be translated to protein, we also investigated whether capillary brain endothelial cells express the HBD-2 peptide. The expression of the HBD-2 peptide in endothelial cells was confirmed by immunofluorescence staining for HBD-2 peptide and by Western blotting. The secretion of HBD-2 was confirmed by measuring the HBD-2 in the supernatants by ELISA. In good accordance with the inducible nature of HBD-2 in keratinocytes and epithelial cells, we observed a definite increase in the expression of HBD-2 upon exposure to C. pneumoniae.

In our experiments, heat-inactivated $C$. pneumoniae was still able to induce the expression and secretion of HBD-2, albeit at lower levels (Figures 5. and 8.). This suggests that, among the potential products of bacteria, one candidate could be a heat-resistant lipopolysaccharide. On the other hand, heat-labile compounds, such as outer membrane proteins or other yet unidentified factors, might also be candidates for HBD-2 activation.

Infection of human endothelial cells with $C$. pneumoniae results in the stimulation of a wide variety of cytokines, adhesion molecules, chemokines and proteins with procoagulant activity $[88,120]$, which furnishes evidence of the role of infection with this bacterium in the atherogenic process $[121,122]$.

The role of $\beta$-defensin peptide in endothelial cell biology is not clear. It might be that endothelial cells use defensins to exert antimicrobial activity. Defensins also exert a broad spectrum of immunological effects [123, 124]; human ß-defensins may attract immature 
dendritic cells, naive T-cells and memory T-cells [125], which suggests that these defensins are involved in orchestrating an immune response [126], and it may be hypothesized that HBD-2 contributes to the possible innate immunity involved in atherosclerosis. Further studies are necessary to elucidate the role of HBDs in atherosclerosis or stroke.

The result demonstrating that HBD-2 is expressed and produced in the human brain capillary endothelial cells upon infection with $C$. pneumoniae is novel and provides evidence that HBD-2 plays a role in the early immune responses to $C$. pneumoniae and probably in the immunopathogenesis of atherosclerosis. This result might facilitate an understanding of the pathomechanism of the inflammation-mediated events of atherosclerosis or stroke in connection with C. pneumoniae infection. 


\section{SUMMARY AND NEW RESULTS}

1. Our results revealed an association between the $-374 \mathrm{~T} / \mathrm{A}$ polymorphism of the RAGE promoter and multiple sclerosis. The genetic variant -374AA (which has previously been shown to exert significant effects on transcriptional activity) can be considered a preventive factor as regards the occurrence of MS. Our findings support the view that RAGE plays a role in the development of MS.

2. Polymorphism of NOD1 G796A alone did not prove to be a risk factor for stroke in general, but in association with Chlamydophila pneumoniae infection it appeared to be accompanied by an increased risk of the development of stroke.

3. The variations in the genes encoding human $\beta$-defensin- 1 and -2 may be associated with the risk of severe acute pancreatitis and also with infected acute pancreatitis.

4. The results of in vitro experiments indicate that HBD-2 is expressed and produced in the human brain capillary endothelial cells upon infection with $C$. pneumoniae, and provide evidence that HBD-2 plays a role in the early immune responses to $C$. pneumoniae and probably in the immunopathogenesis of atherosclerosis. 


\section{REFERENCES}

1. Kanneganti TD, Lamkanfi M, Núñez G. Intracellular NOD-like receptors in host defense and disease. Immunity. 2007 Oct;27(4):549-59.

2. Takeuchi O, Akira S. Pattern recognition receptors and inflammation. Cell. 2010 Mar 19;140(6):805-20.

3. Ganz T. Defensins: antimicrobial peptides of innate immunity. Nat Rev Immunol. $2003 ; 3: 710-720$.

4. Sims GP, Rowe DC, Rietdijk ST, Herbst R, Coyle AJ. HMGB1 and RAGE in inflammation and cancer. Annu Rev Immunol. 2010 Mar;28:367-88.

5. Strober W, Murray PJ, Kitani A, Watanabe T. Signalling pathways and molecular interactions of NOD1 and NOD2. Nat Rev Immunol. 2006 Jan;6(1):9-20.

6. Tsuchiya N, Ohashi J, Tokunaga K. Variations in immune response genes and their associations with multifactorial immune disorders. Immunol Rev. 2002 Dec;190:16981.

7. Bucciarelli LG, Wendt T, Rong L, Lalla E, Hofmann MA, Goova MT, Taguchi A, Yan SF, Yan SD, Stern DM, Schmidt AM. RAGE is a multiligand receptor of the immunoglobulin superfamily: implications for homeostasis and chronic disease. Cell Mol Life Sci. 2002; 59:1117-1128.

8. Ramasamy R, Vannuci SJ, Yan SS, Herold K, Yan SF, Schmidt AM. Advanced glycation end products and RAGE: a common thread in aging, diabetes, neurodegeneration, and inflammation. Glycobiology. 2005;15:16R-28R.

9. Yan SD, Chen X, Fu J, Chen M, Zhu H, Roher A, Slattery T, Zhao L, Nagashima M, Morser J, Migheli A, Nawroth P, Stern D, Schmidt AM. RAGE and amyloid-beta peptide neurotoxicity in Alzheimer's disease. Nature 1996;382:685-691.

10. Hofmann MA, Drury S, Fu C, Qu W, Taguchi A, Lu Y, Avila C, Kambham N, Bierhaus A, Nawroth P, Neurath MF, Slattery T, Beach D, McClary J, Nagashima M, Morser J, Stern D, Schmidt AM. RAGE mediates a novel proinflammatory axis: the cell surface receptor for S100/calgranulin polypeptides. Cell 1999;97:889-901.

11. Bierhaus A, Humpert PM, Morcos M, Wendt T, Chavakis T, Arnold B, Stern DM, Nawroth PP. Understanding RAGE, the receptor for advanced glycation end products. J Mol Med 2005;83:876-886. 
12. Qin J, Goswami R, Dawson S, Dawson G. Expression of the receptor for advanced glycation end products in oligodendrocytes in response to oxidative stress. $J$ Neurosci Res. 2008;86:2414-2422.

13. Huttunen HJ, Rauvala H. Amphoterin as an extracellular regulator of cell motility: from discovery to disease. J Intern Med. 2004 Mar;255(3):351-66.

14. Yan SD, Schmidt AM, Anderson GM, Zhang J, Brett J, Zou YS, Pinsky D, Stern D. Enhanced cellular oxidant stress by the interaction of advanced glycation end products with their receptors/binding proteins. J Biol Chem. 1994;269:9889-9897.

15. Wautier MP, Chappey O, Corda S, Stern DM, Schmidt A, Waultier JL. Activation of NADPH oxidase by AGE links oxidant stress to altered gene expression via RAGE. Am J Physiol Endocrinol Metab. 2001;280:E685-E694.

16. Wautier JL, Schmidt AM. Protein glycation: a firm link to endothelial cell dysfunction. Circ Res. 2004;95:233-238.

17. Park L, Raman KG, Lee KJ, Lu Y, Ferran LJ, Chow WS, Stern D, Schmidt AM. Suppression of accelerated diabetic atherosclerosis by the soluble receptor for advanced glycation endproducts. Nat Med. 1998;4:1025-1031.

18. Lue LF, Walker DG, Brachova L, Beach TG, Rogers J, Schmidt AM, Stern DM, Yan SD. Involvement of microglial receptor for advanced glycation end products (RAGE) in Alzheimer's disease: identification of a cellular activation mechanism. Exp Neurol. 2001;171:29-45.

19. Sasaki N, Takeuchi M, Chowei H Kikuchi S, Hayashi Y, Nakano N, Ikeda H, Yamagishi S, Kitamoto T, Saito T, Makita Z. Advanced glycation end products (AGE) and their receptor (RAGE) in the brain of patients with Creutzfeld-Jacob disease with prion plaques. Neurosci Lett. 2002;326:117-120.

20. Ma L, Nicholson LFB. Expression of the receptor for advanced glycation end products in Huntington's disease caudate nucleus. Brain Res. 2004;1018:10-17.

21. Hudson BI, Stickland MH, Grant PJ. Identification of polymorphisms in the receptor for advanced glycation end products (RAGE) gene. Prevalence in type 2 diabetes and ethnic groups. Diabetes 1998;47:1155-1157.

22. Hudson BI, Stickland MH, Futers TS, Grant PJ. Effects of novel polymorphisms in the RAGE gene on transcriptional regulation and their association with diabetic retinopathy. Diabetes 2001;50:1505-1511.

23. Hofmann MA, Drury S, Hudson BI, Gleason MR, Qu W, Lu Y, Lalla E, Chitnis S, Monteiro J, Stickland MH, Bucciarelli LG, Moser B, Moxley G, Itescu S, Grant PJ, 
Gregersen PK, Stern DM, Schmidt AM. RAGE and arthritis: the G82S polymorphism amplifies the inflammatory response. Genes Immun. 2002;3:123-135.

24. Peyrin-Biroulet L, Vignal C, Dessein R, Simonet M, Desreumaux P, Chamaillard M. NODs in defence: from vulnerable antimicrobial peptides to chronic inflammation. Trends Microbiol. 2006 Oct;14(10):432-8.

25. Fritz JH, Ferrero RL, Philpott DJ, Girardin SE. Nod-like proteins in immunity, inflammation and disease. Nat Immunol. 2006 Dec;7(12):1250-7.

26. Bell JK, Mullen GE, Leifer CA, Mazzoni A, Davies DR, Segal DM: Leucine-rich repeats and pathogen recognition in Toll-like receptors. Trends Immunol. 2003, 24:528-533.

27. Chamaillard M, Hashimoto M, Horie Y, Masumoto J, Qiu S, Saab L, Ogura Y, Kawasaki A, Fukase K, Kusumoto S, Valvano MA, Foster SJ, Mak TW, Nuñez G, Inohara N. An essential role for NOD1 in host recognition of bacterial peptidoglycan containing diaminopimelic acid. Nat Immunol. 2003, 4:702-707.

28. Rietdijk ST, Burwell T, Bertin J, Coyle AJ. Sensing intracellular pathogens-NOD-like receptors. Curr Opin Pharmacol. 2008 Jun;8(3):261-6.

29. Zouali H, Lesage S, Merlin F, Cézard JP, Colombel JF, Belaiche J, Almer S, Tysk C, O'Morain C, Gassull M, Christensen S, Finkel Y, Modigliani R, Gower-Rousseau C, Macry J, Chamaillard M, Thomas G, Hugot JP; EPWG group; EPIMAD group. CARD4/NOD1 is not involved in inflammatory bowel disease. Gut 2003;52:71-74.

30. Zhao C, Wang I, Lehrer RI. Widespread expression of hBD-1 in human secretory glands and epithelia. FEBS Lett. 1996; 396: 319-322.

31. Schneider JJ, Unholzer A, Schaller M, Schäfer-Korting M, Korting HC: Human defensins. J Mol Med. 2005; 83: 587-595.

32. Donnarumma G, Paoletti I, Buommino E, Orlando M, Tufano MA, Baroni A. Malassezia furfur induces the expression of $\beta$-defensin- 2 in human keratinocytes in a protein kinase C-dependent manner. Arch Dermatol Res. 2004 Apr;295(11):474-81.

33. Singh PK, Jia HP, Wiles K, Hesselberth J, Liu L, Conway BA, Greenberg EP, Valore EV, Welsh MJ, Ganz T, Tack BF, McCray PB Jr. Production of beta-defensins by human airway epithelia. Proc Natl Acad Sci U S A. 1998 Dec 8;95(25):14961-6.

34. Yang D, Chertov O, Bykovskaia SN, Chen Q, Buffo MJ, Shogan J, Anderson M, Schröder JM, Wang JM, Howard OM, Oppenheim JJ. Beta-defensins: linking innate and adaptive immunity through dendritic and T cell CCR6. Science. 1999 Oct 15;286(5439):525-8. 
35. Schutte BC, Mitros JP, Bartlett JA, Walters JD, Jia HP, Welsh MJ, Casavant TL, McCray PB Jr. Discovery of five conserved beta-defensin gene clusters using a computational search strategy. Proc Natl Acad Sci USA 2002; 99: 2129-2133.

36. Schnapp D, Reid CJ, Harris A: Localization of expression of human beta defensin-1 in the pancreas and kidney. J Pathol 1998; 186:99-103.

37. Zhao C, Wang I, Lehrer RI: Widespread expression of beta-defensin hBD-1 in human secretory glands and epithelial cells. FEBS Lett. 1996; 396: 319-322.

38. Duits LA, Ravensbergen B, Rademaker M, Hiemstra PS, Nibbering PH. Expression of $\beta$-defensin 1 and 2 mRNA by human monocytes, macrophages and dendritic cells. Immunology 2002; 106: 517-525.

39. Hao H-N, Zhao J, Lotoczky G, Grever WE, Lyman WD. Induction of human $\beta$ defensin-2 expression in human astrocytes by lipopolysaccharide and cytokines. $J$ Neurochem. 2001; 77: 1027-1035.

40. Dork T, Stuhrmann M: Polymorphisms of the human beta-defensin-1 gene. Mol Cell Probes. 1998; 12: 171-173.

41. den Dunnen JT, Antonarakis SE: Mutation nomenclature extensions and suggestions to describe complex mutations: a discussion. Hum Mutat. 2000; 15: 7-12.

42. Sun CQ, Arnold R, Fernandez-Golarz C, Parrish AB, Almekinder T, He J, Ho SM, Svoboda P, Pohl J, Marshall FF, Petros JA: Human beta-defensin-1, a potential chromosome $8 \mathrm{p}$ tumor suppressor: control of transcription and induction of apoptosis in renal cell carcinoma. Cancer Res. 2006; 66: 8542-8549.

43. Tesse R, Cardinale F, Santostasi T, Polizzi A, Manca A, Mappa L, Iacoviello, De Robertis F, Logrillo VP, Armenio L: Association of ß-defensin-1 gene polymorphisms with Pseudomonas aeruginosa airway colonization in cystic fibrosis. Genes Immun 2008; 9: 57-60.

44. Levy H, Raby BA, Lake S, Tantisira KG, Kwiatkowski D, Lazarus R, Silverman EK, Richter B, Klimecki WT, Vercelli D, Martinez FD, Weiss ST: Association of defensin beta I gene polymorphisms with asthma. J Allergy Clin Immunol 2005; 115: 252-258.

45. Matsushita I, Hasegawa K, Nakata K, Yasuda, K, Tokunaga K, Keicho N. Genetic variants of human beta-defensin-I and chronic obstructive pulmonary disease. Biochem Biophys Res Commun 2002;29:17-22.

46. Kocsis ÁK, Lakatos PL, Somogyvári F, Fuszek P, Papp J, Fischer S, Szamosi T, Lakatos L, Hofner P, Mándi Y: Association of beta- defensin 1 nucleotide polymorphisms with Crohn's disease. Scand J Gastroenterol 2007; 17: 1-9. 
47. Wehkamp J, Schmid M, Fellermann K, Stange EF. Defensin deficiency, intestinal microbes, and the clinical phenotypes of Crohn's disease. J Leukoc Biol. 2005 Apr;77(4):460-5.

48. Hollox EJ, Armour JA, Barber JC: Extensive normal copy number variation of a betadefensin antimicrobial-gene cluster. Am J Hum Genet 2003; 73: 591-600.

49. Linzmeier RM, Ganz T: Human defensin gene copy number polymorphisms: comprehensive analysis of independent variation in $\alpha$ - and $\beta$-defensin regions at $8 \mathrm{p} 22$ p23. Genomics 2005; 86: 423-430.

50. Sargen K, Demaine AG, Kingsnorth AN: Cytokine gene polymorphisms in acute pancreatitis. JOP 2000; 1: 24-35.

51. Hofner P, Balog A, Gyulai Z, Farkas G, Rakonczay Z, Takács T: Polymorphism on the IL-8 gene, but not in the TLR4 gene, increases the severity of acute pancreatitis. Pancreatology 2006; 6: 542-548.

52. Poser CM, Paty DW, Scheimberg L, McDonald WI, Davis FA, Ebers GC, Johnson KP, Sibley WA, Silberberg DH, Tourtellotte WW. New diagnostic criteria for multiple sclerosis: guidelines for research protocols. Ann Neurol. 1983;13:227-231.

53. Thompson AJ, Montalban X, Barkhof F, Brochet B, Filippi M, Miller DH, Polman $\mathrm{CH}$, Stevenson VL, McDonald WI. Diagnostic criteria for primary progressive multiple sclerosis: a position paper. Ann Neurol. 2000;47:831-835.

54. Bencsik K, Rajda C, Fuvesi J, Klivenyi P, Jardanhazy T, Torok M Vécsei L. The prevalence of multiple sclerosis, distribution of clinical forms of the disease and functional status of patients in Csongrad County, Hungary Eur Neurol. 2001;46:206209.

55. Sternberg Z, Weinstock-Guttman B, Hojnacji D, Zamboni P, Zivadinov R, Chadha K, Lieberman A, Kazim L, Drake A, Rocco P, Grazioli E, Munschauer F. Soluble receptor for advanced glycation end products in multiple sclerosis: a potential marker of disease severity. Mult Scler. 2008;14:759-763.

56. Kiechl S, Egger G, Mayr M, Wiedermann CJ, Bonora E, Oberhollenzer F, Muggeo M, $\mathrm{Xu} \mathrm{Q}$, Wick G, Poewe W, Willeit J. Chronic infections and risk of carotid atherosclerosis: prospective results from a large population study. Circulation 2001; 103: $1064-1070$.

57. Gulcher JR, Gretarsdottir S, Helgadottir A, Stefansson K. Genes contributing to risk for common forms of stroke. Trends Mol Med 2005; 11: 217-224. 
58. Lindsberg PJ and Grau AJ. Inflammation and infections as risk factors for ischemic stroke. Stroke 2003; 34: 2518-2532.

59. Morgan L and Humphries SE. The genetics of stroke. Curr Opin Lipidol 2005; 16: 193-199.

60. Matarin M, Singleton A, Hardy J, Meschia J. The genetics of ischemic stroke. J Intern Med. 2010 Feb;267(2):139-55.

61. Elkind MSV, Ramakrishnan P, Moon YP, Boden-Albala B, Liu KM, Spitalnik SL, Rundek T, Sacco RL, Paik MC. Infectious burden and risk of stroke. Arch Neurol 2010; 67: 33-38.

62. Anzini A, Cassone A, Rasura M, Ciervo A, Beccia M, Di Lisi F, Fieschi C. Chlamydia pneumoniae infection in young stroke patients: a case-control study. Eur J Neurol 2004; 11: 321-327.

63. Elkind MS, Tondella ML, Feikin DR, Fields BS, Homma S, Di Tullio MR. Seropositivity to Chlamydia pneumoniae is associated with risk of first ischemic stroke. Stroke 2006; 37: 790-795.

64. Elkind MSV, Lin I-F, Grayston JT, Sacco RL. Chlamydia pneumoniae and the risk of first ischemic stroke: the Northern Manhattan stroke study. Stroke 2001; 31: 15211525 .

65. Heuschmann PU, Neureiter D, Gesslein M, Craiovan B, Maass M, Faller G, Beck G, Neundoerfer B, Kolominsky-Rabas PL. Association between infection with Helicobacter pylori and Chlamydia pneumoniae and risk of ischemic stroke subtypes: results from a population-based case-control study. Stroke 2001; 32: 2253-2258.

66. Madre JG, Garcia JL, Gonzalez RC, Montero JM, Paniagua EB, Escribano JR, Martinez JD, Cenjor RF. Association between seropositivity to Chlamydia pneumoniae and acute ischemic stroke. Eur J Neurol 2002; 9: 303-306.

67. Piechowski-Jozwiak B, Mickielewicz A, Gaciong Z, Berent H, Kwiecinski H. Elevated levels of anti-Chlamydia pneumoniae IgA and IgG antibodies in young adults with ischemic stroke. Acta Neurol Scand. 2007; 116: 144-149.

68. Apfalter P, Barousch W, Nehr M, Willinger B, Rotter M, Hirschl AM. No evidence of involvement of Chlamydia pneumoniae in severe cerebrovascular atherosclerosis by means of quantitative realtime polymerase chain reaction. Stroke 2004; 35: 2024 2028.

69. Glader CA, Stegmayr B, Boman J, Stenlund H, Weinehall L, Hallmans G, Dahlén GH. Chlamydia pneumoniae antibodies and high lipoprotein(a) levels do not predict 
ischemic cerebral infractions: results from a nested case control study in Northern Sweden. Stroke 1999; 30: 2013-2018.

70. Paterson DL, Hall J, Rasmussen SJ, Timms P. Failure to detect Chlamydia pneumoniae in atheroclerotic plaques of Australian patients. Pathology 1998; 30: 169172.

71. Inohara M, Nunez G. NODs: intracellular proteins involved in inflammation and apoptosis. Nat Rev Immunol 2001; 3: 371-382.

72. Le Bourhis L, Werts C. Role of Nods in bacterial infection. Microbes Infect 2007; 9: 629-636.

73. Cameiro LAM, Magalhaes JG, Tattoli I, Philpott DJ, Travassos LH. Nod-like proteins in inflammation and disease. J Pathol 2008; 214: 136-148.

74. Benko Sz, Philpott DJ, Girardin SE. The microbial and danger signals that activate Nod-like receptors. Cytokine 2008; 43: 368-373.

75. Chen G, Shaw MH, Kim YG, Nuñez G. NOD-like receptors: role in innate immunity and inflammatory disease. Annu Rev Pathol. 2009;4:365-98.

76. Kaparakis M, Philpott DJ, Ferrero RL. Mammalian NLR proteins; discriminating foe from friend. Immunol Cell Biol. 2007 Aug-Sep;85(6):495-502.

77. Voss E, Wehkamp J, Wehkamp K, Stange EF, Schröder JM, Harder J. NOD2/CARD15 mediates induction of the antimicrobial peptide human betadefensin-2. J Biol Chem. 2006 Jan 27;281(4):2005-11.

78. Opitz B, Förster S, Hocke AC, Maass M, Schmeck B, Hippenstiel S, Suttorp N, Krüll M. Nod1-mediated endothelial cell activation by Chlamydophila pneumoniae. Circ Res 2005; 96: 319-326.

79. Beger HG, Bittner R, Block S, Büchler M: Bacterial contamination of pancreatic necrosis. A prospective clinical study. Gastroenterology 1986; 81: 433-438.

80. Juvonen PO, Alhava EM, Takala JA: Gut permeability in patients with acute pancreatitis. Scand J Gastroenterol 2000; 35: 1314-1318.

81. Ammori BJ, Leeder PC, King RF, Barclay GR, Martin IG, Larvin M, McMahon MJ: Early increase in intestinal permeability in patients with severe acute pancreatitis: correlation with endotoxemia, organ failure, and mortality. J Gastrointest Surg 1999; 3: $252-262$.

82. Yasuda T, Takeyama Y, Ueda T, Shinzeki M, Sawa H, Nakajima T, Kuroda Y: Breakdown of intestinal mucosa via accelerated apoptosis increases intestinal permeability in experimental severe acute pancreatitis. J Surg Res 2006;135: 18-26. 
83. Masamune A, Kikuta K, Watanabe T, Satoh K, Satoh A, Shimosegawa T: Pancreatic stellate cells express Toll-like receptors. J Gastroenterol 2008; 43: 352-362.

84. Müller CA, Autenrieth IB, Peschel A: Innate defenses of the intestinal epithelial barrier. Cell Mol Life Sci. 2005; 62: 1297-1307.

85. Romano Carratelli C, Nuzzo I, Cozzolino D, Bentivoglio C, Paolillo R, Rizzo A. Relationship between Chlamydia pneumoniae infection, inflammatory markers, and coronary heart diseases. Int Immunopharmacol 2006; 6: 848-853.

86. Romano Carratelli C, Mazzola N, Paolillo R, Sorrentino S, Rizzo A. Toll-like receptor-4 (TLR4) mediates human b-defensin-2 (HBD-2) induction in response to Chlamydia pneumoniae in mononuclear cells. FEMS Immunol Med Microbiol 2009; 57: 116-124.

87. Rizzo A, Paolillo R, Buommino E, Lanza AG, Guida L, Annunziata M, Carratelli CR.. Modulation of cytokine and beta-defensin 2 expressions in human gingival fibroblasts infected with Chlamydia pneumoniae. Int Immunopharmacol 2008; 8: 1239-1247.

88. Summersgill JT, Molestina RE, Miller RD and Ramirez JA. Interactions of Chlamydia pneumoniae with human endothelial cells. J Infect Dis 2000; 181(Suppl 3): S479S482.

89. Roquer J, Segura T, Serena J and Castillo J. Endothelial dysfunction, vascular disease and stroke: the ARTICO study. Cerebrovasc Dis. 2009; 27: S25-S37.

90. Tintore M, Rovira A, Martinez MJ, Rio J, Diaz-Villoslada P, Brieva L, Borrás C, Grivé E, Capellades J, Montalban X. Isolated demyelinating syndromes: comparison of different MR imaging criteria to predict conversion to clinically definite multiple sclerosis. Am J Neuroradiol 2000;21:702-706.

91. McDonald WI, Compston A, Edan G, Goodkin D, Hartung HP, Lublin FD McFarland HF, Paty DW, Polman CH, Reingold SC, Sandberg-Wollheim M, Sibley W, Thompson A, van den Noort S, Weinshenker BY, Wolinsky JS. Recommended diagnostic criteria for multiple sclerosis: guidelines from the International Panel on the Diagnosis of Multiple Sclerosis. Ann Neurol 2001;50:121-127.

92. Kurtzke JF Rating neurologic impairment in multiple sclerosis: an expanded disability status scale (EDSS). Neurology 1983;33:1442-1452.

93. Ranson JH: Etiological and prognostic factors in human acute pancreatitis: a review. Am J Gastroenterol 1982;77:633-638. 
94. Wallace AM, He J-Q, Burkett KM, Ruan J, Connett JE, Anthonisen NR, Paré PD, Sandford AJ: Contribution of alpha- and beta-defensins to lung function decline and infection in smokers: an association study. Resp Res 2006;7:76-80.

95. Szilagyi A, Blasko B, Szilassy D, Fust G, Sasvari-Szekely M, Ronai Zs: Real-time PCR quantification of human complement $\mathrm{C} 4 \mathrm{~A}$ and $\mathrm{C} 4 \mathrm{~B}$ genes. BMC Genetics 2006;7:1.

96. Prudhomme JG, Sherman IW, Land KM, Moses AV, Stenglein S, Nelson JA. Studies of Plasmodium falciparum cytoadherence using immortalized human brain capillary endothelial cells. Int J Parasitol 1996; 26: 647-655.

97. Maass M, Bartels C, Engel PM, Mamat U, Sievers HH. Endovascular presence of viable Chlamydia pneumoniae is a common phenomenon in coronary artery disease. $J$ Am Coll Cardiol. 1998; 31: 827-832.

98. Falcone C, Campo I, Emanuele E, Buzzi MP, Geroldi D, Belvito C Zorzetto M, Sbarsi I, Cuccia M. 374 T/A polymorphism of the RAGE gene promoter in relation to severity of coronary atherosclerosis. Clin Chim Acta 2005;354:111-116.

99. Tonk M, Haan J. A review of genetic causes of ischemic and hemorrhagic stroke. $J$ Neurol Sci. 2007; 257: 273-279.

100. Pola R, Flex A, Gaetani E, Flore R, Serricchio M, Pola P. Synergistic effect of $174 \mathrm{G} / \mathrm{C}$ polymorphism of the interleukin- 6 gene promoter and $469 \mathrm{E} / \mathrm{K}$ polymorphism of intercellular adhesion molecule-1 gene in Italian patients with history of ischemic stroke. Stroke 2003; 34: 881-885.

101. Humphries SE, Morgan L. Genetic risk factors for stroke and carotid atherosclerosis: insights into pathophysiology from candidate gene approaches. Lancet Neurol 2004; 3: $227-236$.

102. Philpott DJ, Giardin SE. The role of Toll-like receptors and Nod proteins in bacterial infection. Mol Immunol 2004; 41: 1099-1108.

103. Kiechl S, Lorenz E, Reindl M, Wiedermann CJ, Oberhollenzer F, Bonora E, Willeit J, Schwartz DA. Toll-like receptor 4 polymorphisms and atherogenesis. $N$ Engl J Med 2002; 347: 185-192.

104. Hysi P, Kabesch M, Moffatt MF, Schedel M, Carr D, Zhang Y, Boardman B, von Mutius E, Weiland SK, Leupold W, Fritzsch C, Klopp N, Musk AW, James A, Nunez G, Inohara N, Cookson WO. NOD1 variation, immunoglobulin E and asthma. Hum Mol Genet 2005; 14: 935-940. 
105. Weidinger S, Klopp N, Rummler L, Wagenpfeil S, Novak N, Baurecht HJ, Groer W, Darsow U, Heinrich J, Gauger A, Schafer T, Jakob T, Behrendt H, Wichmann HE, Ring J, Illig T. Association of NOD1 polymorphisms with atopic eczema and related phenothypes. J Allergy Clin Immunol 2005; 116: 177-184.

106. Tanabe T, Ishige I, Suzuki Y, Aita Y, Furukawa A, Ishige Y, Uchida K, Suzuki T, Takemura T, Ikushima S, Oritsu M, Yokoyama T, Fujimoto Y, Fukase K, Inohara N, Nunez G, Eishi Y. Sarcoidosis and NOD1 variation with impaired recognition of intracellular Propionibacterium acnes. Biochim Biophys Acta 2006; 1762: 794-801.

107. Pezzilli R, Fantini L: Probiotics and severe acute pancreatitis. JOP 2006; 7: 92-93. 27.

108. Olah A, Belagyi T, Issekutz A, Gamal ME, Bengmark S: Randomized clinical trial of specific lactobacillus and fibre supplement to early enteral nutrition in patients with acute pancreatitis. Br J Surg 2002; 89: 1103-1107.

109. Tromm A, Niewerth U, Khoury M, Baestlein E, Wilhelms G, Schulze J, Stolte M: The probiotic E. coli strain Nissle 1917 for the treatment of collagenous colitis: first results of an open-label trial. Z Gastroenterol 2004; 42:365-369.

110. Rachmilewitz D, Katakura K, Karmeli F, Hayashi T, Reinus C, Rudensky B, Akira S, Takeda K, Lee J, Takabayashi K, Raz E: Toll-like receptor 9 signaling mediates the anti-inflammatory effects of probiotics in murine experimental colitis. Gastroenterology 2004; 126: 520-528.

111. Prado-Montes de Oca E, Garcia-Vargas A, Lozano-Inocencio R, Gallegos-Arreola MP, Sandoval-Ramirez L, Davalos-Rodriguez NO, Figuera LE: Association of betadefensin 1 single nucleotide polymorphisms with atopic dermatitis. Int Arch Allergy Immunol 2007; 142: 211-218.

112. Jurevic RJ, Bai M, Chadwick RB, White TC, Dale BA: Single-nucleotide polymorphisms (SNPs) in human-defensin 1: high throughput SNP assays and association with Candida carriage in type I diabetics and nondiabetic controls. J Clin Microbiol 2003; 41: 90-96.

113. Braida L, Boniotto M, Pontillo A, Tovo PA, Amoroso A, Crovella S: A singlenucleotide polymorphism in the human beta-defensin 1 gene is associated with HIV-1 infection in Italian children. AIDS 2004; 18: 1598-1600.

114. Fellermann K, Stange DE, Schaeffeler E, Schmalzl H, Wehkamp J, Bevins CL, Reinisch W, Teml A, Schwab M, Lichter P, Radlwimmer B, Stange EF: A chromosome 8 gene-cluster polymorphism with low human beta-defensin 2 gene copy 
number predisposes to Crohn disease of the colon. Am J Hum Genet 2006; 79: 439448.

115. Ito D, Murata M, Tanahashi N, Sato H, Sonoda A, Saito I, Watanabe K, Fukuuchi Y. Polymorphism in the promoter of lipopolysaccharide receptor CD14 and ischemic cerebrovascular disease. Stroke 2000; 31: 2661-2664.

116. Yamada Y, Ichiara S, Nishida T. Proinflammatory gene polymorphisms and ischemic stroke. Curr Pharm Des. 2008; 14: 3590-3600.

117. Bandaru VCSS, Laxmi V, Neeraja M, Alladi S, Meena AK, Borgohain R, Keerthi AS, Kaul S. Chlamydia pneumoniae antibodies in various subtypes of ischemic stroke in Indian patients. $J$ Neurol Sci 2008; 272: 115-122.

118. Janssens W, Nuytten H, Dupont LJ, Van Eldere J, Vermeire S, Lambrechts D, Nackaerts K, Decramer M, Cassiman JJ, Cuppens H. Genomic copy number determines functional expression of $\beta$-defensin 2 in airway epithelial cells and associates with chronic obstructive pulmonary disease. Am J Respir Crit Care Med 2010; 163-169.

119. Kawsar HI, Ghosh SK, Hirsch SA, Koon HB, Weinberg A, Jin G. Expression of human b-defensin-2 in intratumoral vascular endothelium and in endothelial cells induced by transforming growth factor b. Peptides 2010; 31: 195-201.

120. Fryer RH, Woods ML, Rogers GM. Chlamydia species infect human vascular endothelial cells and induce procoagulant activity. J Invest Med 1997; 45: 168-174.

121. Högdahl M, Söderlund G, Kihlström E. Expression of chemokines and adhesion molecules in human coronary artery endothelial cells infected with Chlamydia (Chlamydophila) pneumoniae. APMIS 2008; 11: 1082-1088.

122. Gaydos CA. Growth in vascular cells and cytokine production by Chlamydia pneumoniae. J Infect Dis 2000; 181: S473-S468.

123. Mookherjee N, Hancock REW. Cationic host defence peptides: innate immune regulatory peptides as a novel approach for treating infections. Cell Mol Life Sci 2007; 64: 922-933.

124. Niyonsaba F, Ogawa H, Nagaoka I. Human beta-defensin-2 functions as a chemotactic agent for tumour necrosis factor-alpha treated human neutrophils. Immunology 2004; 111: $273-281$.

125. Yang D, Biragyn A, Kwak LW, Oppenheim JJ. Mammalian defensins in immunity: more than just microbicidal. Trends Immunol 2002; 23: 291-296. 
126. Oppenheim JJ, Yang D. Alarmins: chemotactic activators of immune responses. Curr Opin Immunol 2005; 17: 359-365. 


\section{ACKNOWLEDGEMENTS}

I would like to express my most sincere gratitude to Professor Yvette Mándi for introducing me to immunobiology and scientific research and supporting me throughout my $\mathrm{PhD}$ studies.

I thank all the members of the Department of Medical Microbiology and Immunobiology, Faculty of Medicine, University of Szeged for their restless support during my work. I am thankful for the help and advice I received from Dr. Ferenc Somogyvári, Dr. Ágnes Katalin Kocsis, Dr. Péter Hofner, Dr. Balázs Németh, Dr. Valéria Endrész, Dr. Klára Megyeri, Dr. László Orosz, and Dr. Zsófia Gyulai, and for the excellent technical assistance from Györgyi Müller, and for Zsuzsanna Rosztóczy for skilful administration.

I thank my research partners, particularly, Dr. Mária Sasvári-Székely, Dr. Réka Kovács-Nagy and Dr. Eszter Szántai, Department of Medical Chemistry, Molecular Biology and Pathobiochemistry, Semmelweis University, Budapest; Dr. Imre Ocsovszky, Department of Biochemistry, University of Szeged; Dr. György Seprényi, Department of Medical Biology, University of Szeged; Ferenc Fülöp, Department of Pharmaceutical Chemistry, University of Szeged for their help.

I thank my clinical partners, particularly Prof. Dr. László Vécsei, Dr. Sztriha K. László and Dr. Krisztina Bencsik, Department of Neurology, University of Szeged; Dr. Zoltán Szolnoki, Department of Cerebrovascular Diseases, Pándy Kálmán County Hospital, Gyula; Prof. Dr. Tamás Takács and Dr. Annamária Szabolcs, First Department of Internal Medicine, University of Szeged; Prof Dr. Gyula Farkas, Department of Surgery, University of Szeged; Dr. Katalin Tápai, Regional Centre of the Hungarian National Blood Transfusion Service, Szeged.

Finally, I thank all the love, patience and continuous encouragement of my family. 
ANNEX 